\title{
THE TYPES OF PALAEARCTIC SPECIES OF THE FAMILIES APIONIDAE, RHYNCHITIDAE, ATTELABIDAE AND CURCULIONIDAE IN THE COLLECTION OF ÉTIENNE LOUIS GEOFFROY (COLEOPTERA, CURCULIONOIDEA)
}

\author{
M. A. Alonso-Zarazaga*
}

\begin{abstract}
The study of 131 more or less complete Curculionoid specimens of the collection Étienne Louis Geoffroy, conserved in the Muséum d'Histoire Naturelle de Paris (Entomologie) has permitted the identification of several nominal species that were nomina dubia and the establishment of several new synonymies and combinations, and, in some cases, the reversion of precedence following Art. 23.9 of the Code, declaring nomina protecta and nomina oblita. New synonymies are (the first term is the valid name): Lixus filiformis (Fabricius, 1781) = Curculio longus Gmelin, 1790; Lasiorhynchites cavifrons (Gyllenhal, 1833) nom. protectum $=$ Rhinomacer viridis Geoffroy, 1785, nom. oblitum; Byctiscus betulae (Linnaeus, 1758) = Rhinomacer auratus Geoffroy, 1785; Neocoenorrhinus pauxillus (Germar, 1824) nom. protectum = Rhinomacer caeruleus Geoffroy, 1785, nom. oblitum; Deporaus betulae (Linnaeus, 1758) = Curculio nigrostriatus Goeze, 1777 = Rhinomacer niger Geoffroy, $1785=$ Curculio fuliginosus Gmelin, 1790; Coniocleonus hollbergii (Fåhraeus, 1842) = Curculio sulcatus Goeze, $1777=$ Curculio sulcatus Geoffroy, 1785 = Curculio sulcatus Gmelin, 1790; Larinus iaceae (Fabricius, 1775) = Curculio carduelis Goeze, 1777; Hypera postica (Gyllenhal, 1813), nom. protectum = Curculio fasciolatus Geoffroy, 1785, nom. oblitum; Charagmus griseus (Fabricius, 1775) = Curculio cupreosquamosus Goeze, $1777=$ Curculio intersectus Geoffroy, 1785 = Curculio squamosus Gmelin, 1790; Sitona hispidulus (Fabricius, 1777) = Curculio griseus Goeze, 1777 = Curculio modestus Geoffroy, 1785 = Curculio geoffroaei Gmelin, 1790; Aulacobaris cuprirostris (Fabricius, 1787) = Curculio viridisericeus Goeze, 1777; Cleopomiarus plantarum (Germar, 1824), nom. protectum $=$ Curculio nigrostriatus Goeze, $1777=$ Curculio floriger Geoffroy, 1785, nom. oblitum $=$ Curculio subglobosus Gmelin, 1790, nom. oblitum; Anisorhynchus scabrosus (Geoffroy, 1785) = Curculio barbatus Rossi, 1794; Hylobius abietis (Linnaeus, 1758) = Curculio tigris Gmelin, 1790; Sitophilus granarius (Linnaeus, 1758) = Curculio contractus Geoffroy, 1785; Phyllobius pomaceus Gyllenhal, 1834 = Curculio auratus Geoffroy, 1785; Hylobius transversovittatus (Goeze, 1777) = Curculio fascialis Gmelin, 1790. New combinations are: Leucophyes occidentalis (Dieckmann, 1982) (from Leucosomus) and Anisorhynchus scabrosus (Geoffroy, 1785) (from Curculio). The following names have been reinstated (stat. res.) as valid: Trachyphloeus spinosus (Goeze, 1777) for the species known as Trachyphloeus olivieri Bedel, 1883, Lixus pulverulentus (Scopoli, 1763) for the species known as Lixus angustatus (Fabricius, 1775). Hypera melancholica (Fabricius, 1793) is confirmed as the valid name for the species hitherto named Hypera fuscocinerea (Marsham, 1802) or Hypera murina (Fabricius, 1793). The following names are considered nomina dubia, since there is no identifiable type material: Curculio pulex Goeze, 1777, Rhinomacer minutus Geoffroy, 1785, Curculio pulex Gmelin, 1790 (non Goeze, 1777), Rhinomacer striatus Geoffroy, 1785, Rhinomacer fulgidus Geoffroy, 1785, Curculio transversofasciatus Goeze, 1777, Curculio fasciatus Geoffroy, 1785 (non Scopoli, 1763, nec Ström, 1768, nec Degeer, 1775 , nec Müller, 1776), Curculio fuscatus Gmelin, 1790, Curculio sulcatus Goeze, 1777: 410 (non Fabricius, 1775, nec Goeze, 1777: 381), Curculio incisus Geoffroy, 1785, Curculio exaratus Gmelin, 1790, Curculio quadratus Goeze, 1777, Curculio quadrilis Geoffroy, 1785, Curculio griseosericeus Goeze, 1777,
\end{abstract}

* Depto. de Biodiversidad y Biología Evolutiva, Museo Nacional de Ciencias Naturales (CSIC). C/. José Gutiérrez Abascal, 2. 28006 Madrid, Spain. zarazaga@mncn.csic.es 
Curculio communis Geoffroy, 1785, Curculio thoracespinosus Goeze, 1777, Curculio armatus Geoffroy, 1785, Curculio denticulatus Gmelin, 1790 (non Schrank, 1781, nec Geoffroy, 1785), Curculio muricatus Goeze, 1777 (non Drury, 1773), Curculio murinus Geoffroy, 1785 (non Müller, 1764), Curculio fuscipes Geoffroy, 1785, Curculio tesselatus Geoffroy, 1785 (non Fabricius, 1781), Curculio sericeus Goeze, 1777, Curculio villosus Geoffroy, 1785 (non Fabricius, 1781), Curculio sericeus Gmelin, 1790 (non Goeze, 1777 , nec Schaller, 1783, nec Piller \& Mitterpacher, 1783), Curculio virgo Goeze, 1777, Curculio virgo Geoffroy, 1785 (non Goeze, 1777), Curculio virgo Gmelin, 1790 (non Goeze, 1777, nec Geoffroy, 1785), Curculio punctulatus Geoffroy, 1785.

Key words: Curculionidae, Attelabidae, Rhynchitidae, Salpingidae, Étienne Louis Geoffroy, new synonymies, new combinations, nomina protecta, nomina oblita, nomina dubia.

\section{RESUMEN}

\section{Los tipos de especies paleárticas de las familias Apionidae, Rhynchitidae, Attelabidae y Curculionidae en la colección Étienne Louis Geoffroy (Coleoptera, Curculionoidea)}

El estudio de 131 ejemplares de Curculiónidos, más o menos completos, de la colección Étienne Louis Geoffroy conservados en el Muséum d'Histoire Naturelle de París (Entomología) ha permitido identificar varias especies nominales que eran consideradas nomina dubia y establecer varias nuevas sinonimias y combinaciones, e incluso, en algunos casos, recuperar la prioridad de acuerdo con el Art. 23.9 del Código, declarando nomina protecta y nomina oblita. Las nuevas sinonimias son (se indica en primer lugar el nombre válido): Lixus filiformis (Fabricius, 1781) = Curculio longus Gmelin, 1790; Lasiorhynchites cavifrons (Gyllenhal, 1833) nom. protectum = Rhinomacer viridis Geoffroy, 1785, nom. oblitum; Byctiscus betulae (Linnaeus, 1758) = Rhinomacer auratus Geoffroy, 1785; Neocoenorrhinus pauxillus (Germar, 1824) nom. protectum $=$ Rhinomacer caeruleus Geoffroy, 1785, nom. oblitum; Deporaus betulae (Linnaeus, 1758) $=$ Curculio nigrostriatus Goeze, 1777 = Rhinomacer niger Geoffroy, $1785=$ Curculio fuliginosus Gmelin, 1790; Coniocleonus hollbergii (Fåhraeus, 1842) = Curculio sulcatus Goeze, $1777=$ Curculio sulcatus Geoffroy, 1785 = Curculio sulcatus Gmelin, 1790; Larinus iaceae (Fabricius, 1775) = Curculio carduelis Goeze, 1777; Hypera postica (Gyllenhal, 1813), nom. protectum = Curculio fasciolatus Geoffroy, 1785, nom. oblitum; Charagmus griseus (Fabricius, 1775) = Curculio cupreosquamosus Goeze, $1777=$ Curculio intersectus Geoffroy, 1785 = Curculio squamosus Gmelin, 1790; Sitona hispidulus (Fabricius, 1777) = Curculio griseus Goeze, 1777 = Curculio modestus Geoffroy, 1785 = Curculio geoffroaei Gmelin, 1790; Aulacobaris cuprirostris (Fabricius, 1787) = Curculio viridisericeus Goeze, 1777; Cleopomiarus plantarum $($ Germar, 1824), nom. protectum $=$ Curculio nigrostriatus Goeze, $1777=$ Curculio floriger Geoffroy, 1785 , nom. oblitum = Curculio subglobosus Gmelin, 1790, nom. oblitum; Anisorhynchus scabrosus (Geoffroy, $1785)=$ Curculio barbatus Rossi, 1794; Hylobius abietis (Linnaeus, 1758) = Curculio tigris Gmelin, 1790; Sitophilus granarius (Linnaeus, 1758) = Curculio contractus Geoffroy, 1785; Phyllobius pomaceus Gyllenhal, 1834 = Curculio auratus Geoffroy, 1785; Hylobius transversovittatus (Goeze, 1777) = Curculio fascialis Gmelin, 1790. Las nuevas combinaciones son: Leucophyes occidentalis (Dieckmann, 1982) (from Leucosomus) and Anisorhynchus scabrosus (Geoffroy, 1785) (from Curculio). Se han restablecido como válidos los siguientes nombres (stat. res.): Trachyphloeus spinosus (Goeze, 1777) para la especie conocida como Trachyphloeus olivieri Bedel, 1883, y Lixus pulverulentus (Scopoli, 1763) para Lixus angustatus (Fabricius, 1775). Se confirma como nombre válido Hypera melancholica (Fabricius, 1793) para la especie denominada hasta ahora Hypera fuscocinerea (Marsham, 1802) o Hypera murina (Fabricius, 1793). Al no poder indentificar el material tipo se consideran nomina dubia los siguientes nombres: Curculio pulex Goeze, 1777, Rhinomacer minutus Geoffroy, 1785, Curculio pulex Gmelin, 1790 (non Goeze, 1777), Rhinomacer striatus Geoffroy, 1785, Rhinomacer fulgidus Geoffroy, 1785, Curculio transversofasciatus Goeze, 1777, Curculio fasciatus Geoffroy, 1785 (non Scopoli, 1763, nec Ström, 1768, nec Degeer, 1775, nec Müller, 1776), Curculio fuscatus Gmelin, 1790, Curculio sulcatus Goeze, 1777: 410 (non Fabricius, 1775, nec Goeze, 1777: 381), Curculio incisus Geoffroy, 1785, Curculio exaratus Gmelin, 1790, Curculio quadratus Goeze, 1777, Curculio quadrilis Geoffroy, 1785, Curculio griseosericeus Goeze, 1777, Curculio communis Geoffroy, 1785, Curculio thoracespinosus Goeze, 1777, Curculio armatus Geoffroy, 1785, Curculio denticulatus Gmelin, 1790 (non Schrank, 1781, nec Geoffroy, 1785), Curculio muricatus Goeze, 1777 (non Drury, 1773), Curculio murinus Geoffroy, 1785 (non Müller, 1764), Curculio fuscipes Geoffroy, 1785, Curculio tesselatus Geoffroy, 1785 (non Fabricius, 1781), Curculio sericeus Goeze, 1777, Curculio villosus Geoffroy, 1785 (non Fabricius, 1781), Curculio sericeus Gmelin, 1790 (non Goeze, 1777, nec Schaller, 1783, nec Piller \& Mitterpacher, 1783), Curculio virgo Goeze, 1777, Curculio virgo Geoffroy, 1785 (non Goeze, 1777), Curculio virgo Gmelin, 1790 (non Goeze, 1777, nec Geoffroy, 1785), Curculio punctulatus Geoffroy, 1785.

Key words: Curculionidae, Attelabidae, Rhynchitidae, Salpingidae, Étienne Louis Geoffroy, nuevas sinonimias, nuevas combinaciones, nomina protecta, nomina oblita, nomina dubia. 


\section{Introduction}

Étienne Louis Geoffroy (1727-1810) was a medical doctor born in Paris who died in Chartreuse, near Soissons. No obituary was ever published for him, to my knowledge.

Geoffroy (1762) described many insect species in his work devoted to the fauna of the surroundings of Paris, without giving them Linnaean binomina. Binomina were later provided in the abridged edition of his work prepared by Fourcroy (1785) with the binomina proposed by Geoffroy himself. Geoffroy also added some new species in this work, as is credited by the editor's (Fourcroy's) words in the foreword. The papers of Cameron (1988) and d'Aguilar \& Raimbault (1990), and also Colonnelli's comments (1998: 134-5), can be consulted to find very useful data on Geoffroy's entomological works as well as on the authorship of some of the names proposed in these.

His collection is now housed in the Muséum National d'Histoire Naturelle, Section d'Entomologie, in Paris. It is placed in a small wooden cabinet (Fig. 1) with a copper plate reading: "Collection E. L. Geoffroy / Don de Mme Georges Coujard de Laplanche / née Geoffroy de Villeneuve / 1909" (Fig. 2). The collection is made up of 24 wooden drawer-boxes of different sizes, in two columns; the Coleoptera, French and foreign (mostly tropical), take up ten boxes on the right column plus one box covered with green paper on the left column. Leraut (1981) has published a study of the Elateridae of his collection and Caldara (1990) did the same with the Curculionidae Tychiini, but the other insects remain to be studied.

The representatives of the superfamily Curculionoidea can be found in the second box on the right. All the weevils are glued to card squares or rectangles, with the angles cut and Geoffroy's species names written. It seems that the cards have been cut after being written, since the writing is sometimes interrupted at the margins (I note this situation with a vertical line $\mid$ in the treatment of the species). These cards are glued to small cork pieces or to elder pith cylinders, and these, for their part, are glued to the bottom of the box as well (similar to what can be seen in a box of Cerambycidae, Fig. 3).

In the preparation of this study, I had to remove most of the cards bearing small weevils to get them properly identified. These have been placed in a new box in the General Collection (Fig. 4), and Geoffroy's box was provided with a label stating this fact and the number of the new box where the absent specimens are now stored.

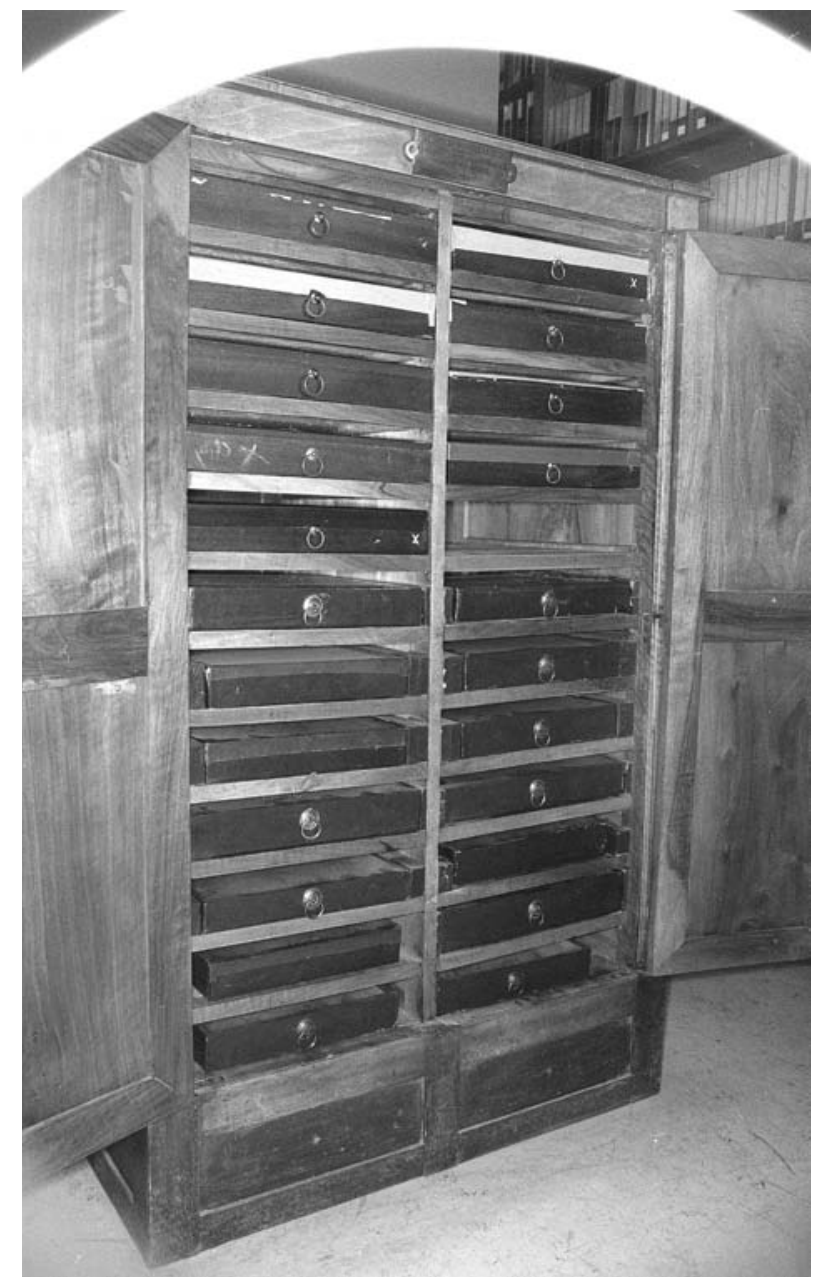

Fig. 1.- Wooden cabinet containing the collection of Étienne Louis Geoffroy in the Paris Museum.

Fig. 1.- Armario de madera que contiene la colección de Étienne Louis Geoffroy en el Muséum National d'Histoire Naturelle, de París.

Some of the larger insects show signs of having been pinned before having been prepared in the way described above. The collection has suffered from Anthrenus attacks and is in a rather poor state of preservation but, happily, most of the weevils are not ruined, except for a few isolated specimens. Nevertheless, the vestiture is often ruined or absent, which makes it very difficult to recognize the extant species.

In some cases, there is no specimen on the card, and there is no evidence that there ever was. At least, there is no gum drop remaining on these cards. This absence was probably the case when the collection was prepared, at a date unknown to me. 


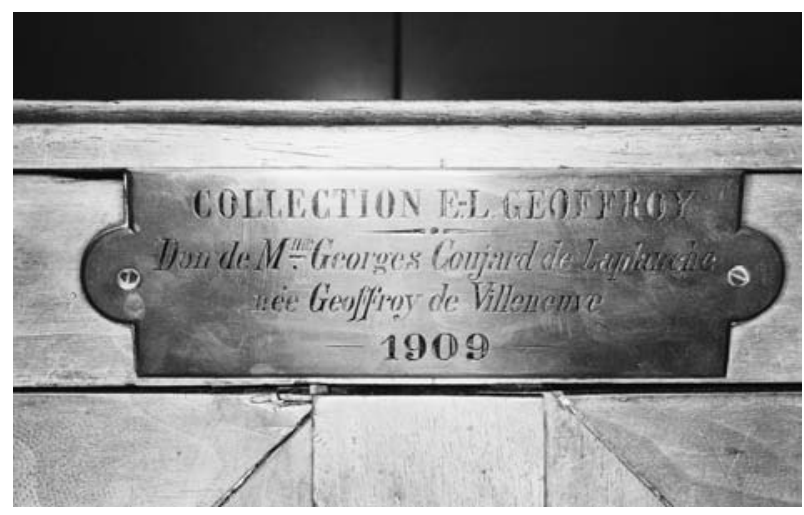

Fig. 2.- Copper plate on the wooden cabinet.

Fig. 2.- Placa de cobre del armario de madera.

\section{Systematic importance of Geoffroy's collection}

Geoffroy's work (1762) is only partially valid for nomenclatural purposes (rejected first in Opinion 228 of the International Commission on Zoological Nomenclature, 1954; later some generic names were deemed to be available, Op. 1754, International Commission on Zoological Nomenclature, 1994). As noted above, Geoffroy did not initially use binominal nomenclature in naming his species, and these have been made nomenclaturally available by later authors using Linnaean nomenclature consistently. The first of these were Goeze (1777), Geoffroy (in Fourcroy, 1785), and Gmelin (1790). Villers (1789) only used names provided by authors preceding him (as far as Geoffroy's species are concerned) and will not be mentioned in the synonymies, unless the name he used is different from that of Goeze or Geoffroy in Fourcroy. No new name appears in the 3rd edition of Geoffroy's work (1799), even though this has a binominal supplement on pages 514-545, recording the species described for the first time in Geoffroy (1785) with somewhat amplified descriptions.

These authors merely redescribed the insects briefly, giving a reference to Geoffroy's work using either the phrase-name heading the Geoffroyan descriptions or the genus and species number. They also gave binominal names to these insects, these being objective synonyms, since they have the same specimen as type (Art. 61.3.4), according to the designations made by other authors or below.

Many of these names have been used by later authors without verifying whether their concepts of the species matched that of Geoffroy (through his types). It is not surprising, therefore, to find impor- tant mistakes needing correction affecting known (not to say banal) species. I have to point out that I first started this study in 1986 by looking at the types of Apionidae, but, shocked by the wrong interpretations, I decided to return to this box, which took longer than expected. However, I had communicated my discoveries to the late lamented Dr. L. Dieckmann (who encouraged me to go on with this study and recognized them by writing, cf. Dieckmann, 1991: 305), and to Drs. R. Caldara (Curculionidae Tychiini; cf. Caldara, 1990) and E. Colonnelli (Curculionidae Ceutorhynchinae). My studies ended with a visit during April 1997.

In the following treatment of every Geoffroyan name, I use as a title (in the order of his 1785 work) the descriptive phrase given by Geoffroy (1762 or 1785 ) and the 1762 page where it is found. Then I give the numbers and words written on the cards, separated by slashes (/), the first line always heading, the second and third (when these exist) below, this direction being taken here as "up" and "down" for the description of the insect placements. After that, I give the objective synonym binominals taken from Goeze (1777), Geoffroy (1785) and Gmelin (1790), and from some other authors if they are based on Geoffroy's descriptions.

A brief description of the weevils found and their condition follows, if needed. If the insects are prepared "head up" (i.e., head directed to the front margin of the card in the direction of reading of the words written on it), this situation is not described, but assumed as normal. It is clear that the collection has suffered re-curation, perhaps by Geoffroy's family for conservation purposes, but it seems that in some cases insects looking similar to those already there have been added, perhaps to enrich the collection. This could explain some of the inconceivable mixes that can be observed and that would not have escaped a fine observer like Geoffroy. I have compared descriptions and specimens very carefully.

I give here the new combinations arising from this study, as well as the pre-1800 synonyms (with some exceptions). I have studied the specimens classified by Geoffroy in his Rhinomacer (Becmare, abbreviated B.) and Curculio (Charançon or Charanson, abbreviated C.). The study of the Anthribidae is set aside for a future contribution. Geoffroy (1762) described 11 Rhinomacer and 34 Curculio. These numbers were raised to 13 and 59 respectively in Geoffroy (1785).

Those species treated only in Geoffroy in Fourcroy (1785) have been separated with an asterisk (*). From number 36 on, I have placed 


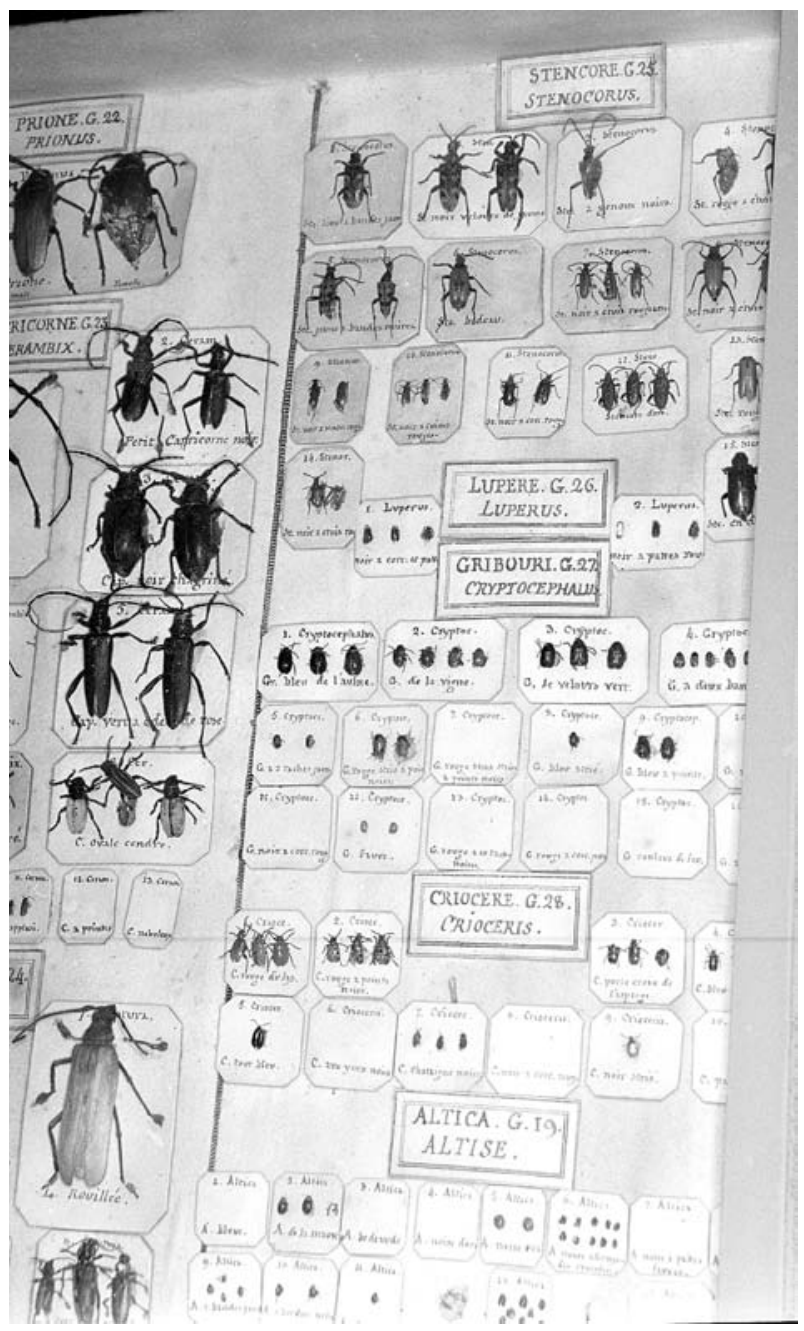

Fig. 3.- A box of Cerambycidae in Geoffroy's collection, to give an idea of the original appearance.

Fig. 3.- Una caja de Cerambycidae de la colección Geoffroy, permite hacerse una idea de la apariencia original.

Geoffroy's (1762) numbers between square brackets. Only the Curculio 60 of his collection has not been described in any of his works. It is also named in its place as a reminder. For the species described for the first time in Geoffroy (1785), I have added the reference to the longer description in Geoffroy (1799) as well. The current taxonomic placement of these names has been checked in Schoenherr (1833-1845), Bedel (1882-1888), Tempère \& Péricart (1989), and the different parts of the Coleopterorum Catalogus, since there is no updated catalogue of the western Palaearctic Region.
One of the goals of the present paper is to contribute to the latter.

All the species have as type locality "les environs de Paris" (the surroundings of Paris), except for the Charansons nos. 36 (Normandie) and 45 (Meudon). Measurements given by Geoffroy (1762, 1785 ) are French lines (one line is $2.25 \mathrm{~mm}$ ).

For lectotype designations, I am following Declaration 44 of the International Commission on Zoological Nomenclature; all designations are made for taxonomic purposes.

\section{Species list}

1. RHINOMACER corpore angusto longo niger; thorace fasciis quatuor albicantibus. Le becmare levrette. Longueur 3 lignes. Largeur 2/3 ligne. Page 269.

1. Rhino / B. levrette.

Curculio elongatus Goeze, 1777: 379 (non Fabricius, 1775, an unidentified Jamaican species, O'Brien \& Wibmer, 1984: 303, perhaps a true Lixus) = Rhinomacer elongatus Geoffroy in Fourcroy, 1785: 113 = Curculio longus Gmelin, 1790: 1758.

There are three glued specimens, measuring from left to right $5.5,6.5$ and $5.5 \mathrm{~mm}$. They belong to the species known for a long time as Lixus elongatus (Goeze, 1777), although this name is invalid and in recent times the correct Lixus filiformis (Fabricius, 1781) has started to be used. I here designate the specimen in the middle as the lectotype and the two other specimens as paralectotypes of the nominal species named by Goeze, Geoffroy and Gmelin. Goeze's and Geoffroy's nominal species were already synonymized with that of Fabricius by Bedel (1886: 270). The synonymy remains as follows:

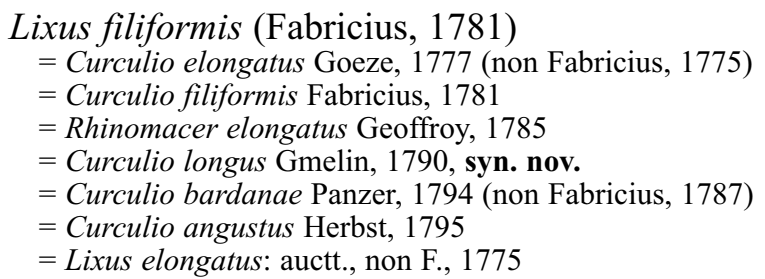

2. RHINOMACER totus viridi-sericeus. Le becmare vert. Longueur 3 lignes. Largeur 2 lignes. Page 270.

\section{Rhino / B. vert.}

Curculio betulae sensu Fabricius, 1775: 130 (non Linnaeus, 1758) = Curculio betulae sensu Goeze, 1777: 350 (non Linnaeus, 1758) $=$ Rhinomacer viridis Geoffroy in Fourcroy, 1785: $113=$ Curculio betulae sensu Gmelin, 1790: 1752 (non Linnaeus, 1758).

There are three dark bluish green specimens; the third lacks a head and prothorax. All of them belong to the same species, Lasiorhynchites cavi- 


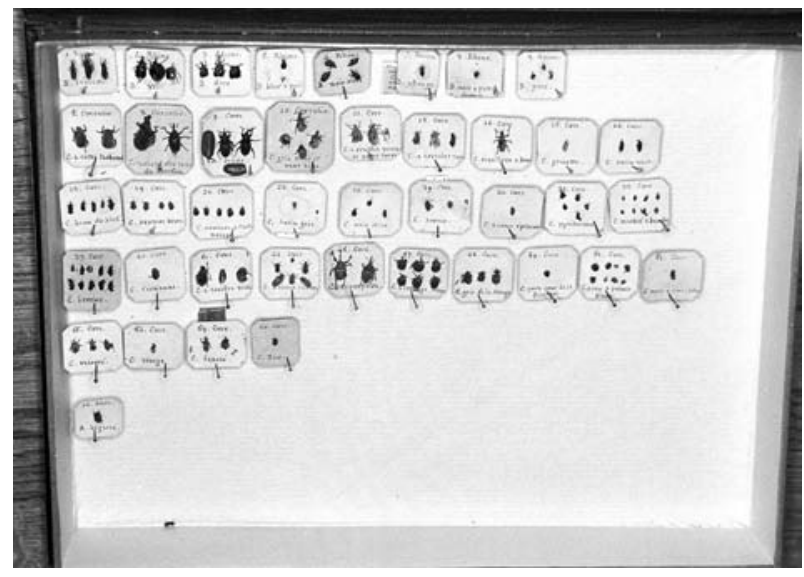

Fig. 4.- The new box with Geoffroy's specimens (including types) in the General Collection.

Fig. 4.-Detalle de una caja nueva con ejemplares de la colección Geoffroy (incluidos tipos) en la Colección General.

frons (Gyllenhal, 1833), described also from Paris. These specimens are in accordance with Geoffroy's short French description ("...étuis... de forme un peu quarrée,... chargés de points qui forment des stries assez serrées, mais peu régulieres."). I hereby designate the first specimen on the left as the lectotype of Rhinomacer viridis Geoffroy, 1785, being in a better conservation state; the others become paralectotypes.

Rhinomacer viridis meets the requirements of Art. 23.9.1.1 and Rhynchites cavifrons (now Lasiorhynchites cavifrons) meets those of Art. 23.9.1.2. In accordance with Art. 23.9.2, I hereby consider that the younger name is valid for this species and give evidence that the conditions of Art. 23.9.1.2 are met by quoting the following references: Abbazzi \& Osella, 1992; Abbazzi et al., 1995; Angelov, 1964, 1972, 1981; Brakman, 1966; Burakowski et al., 1992; Giovanleonardo \& Osella, 2001; Gønget, 2003; Heijerman, 1993; Hoffmann, 1958; Holecová \& Sukupová, 2000; Holecová \& Zach, 1996; Horčičko, 2002; Koch, 1992; Kubisz et al., 1998; Lohse, 1981; Lucht, 1987; Lundberg, 1995; Morris, 1990; Podlussány, 2001; Poiras, 1998; Pye, 1972; Scherf, 1964; Stoltze \& Pihl, 1998; Strejček, 1993; Tempère \& Péricart, 1989; Wanat \& Mokrzycki, 2005; Welch, 2005.

The synonymy is as follows:

Lasiorhynchites cavifrons (Gyllenhal, 1833)

$=$ Curculio betulae sensu Goeze, 1777 (non Linnaeus, 1758)

$=$ Rhinomacer viridis Geoffroy in Fourcroy, 1785 nomen oblitum
= Curculio betulae sensu Gmelin, 1790 (non Linnaeus, 1758)

= Rhynchites pubescens sensu Herbst, 1797 (non Fabricius, 1775)

= Rhynchites cavifrons Gyllenhal, 1833, nomen protectum

The synonymy of Rhinomacer viridis Geoffroy in Voss (1939: 91) with Byctiscus betulae (Linnaeus, 1758 ) is to be suppressed. This erroneous synonymy derives from Schoenherr (1833: 222-3) (sub Rhynchites betuleti Fabricius), and was followed by Bedel (1886: 222-3).

3. RHINOMACER viridi-auratus, subtus nigroviolaceus. Le becmare doré. Longueur 2 lignes. Largeur 1 1/2 ligne. Page 270.

3. Rhino / B. doré.

Curculio populi sensu Goeze, 1777: 351 (non Linnaeus, 1758, nec Scopoli, 1763) = Rhinomacer auratus Geoffroy in Fourcroy, 1785: 113 = Curculio populi sensu Gmelin, 1790: 1752 (non Linnaeus, 1758, nec Scopoli, 1763).

There are also three glued specimens, the third formed only by a hind body with dark blue-violet elytra, which seems to belong to a Lasiorhynchites species [maybe also to Lasiorhynchites cavifrons (Gyllenhal, 1833)]. The first is a female of Byctiscus betulae (Linnaeus, 1758), the second a small male of Rhynchites bacchus (Linnaeus, 1758), both of a golden green colour. Schoenherr (1833: 222) synonymized the records of Geoffroy and Gmelin with Byctiscus populi (Linnaeus, 1758) (sub Rhynchites). Bedel (1886: 223) synonymized Geoffroy's nominal species with the same species, again erroneously. I hereby designate as the lectotype of Geoffroy's species the first specimen (female of Byctiscus betulae). The synonymy is as follows:

Byctiscus betulae (Linnaeus, 1758)

$=$ Curculio betulae Linnaeus, 1758

= Curculio violaceus Poda, 1761 (non Linnaeus, 1758)

= Rhinomacer alni Müller, 1776

= Rhinomacer bispinus Müller, 1776

= Rhinomacer inermis Müller, 1776

= Rhinomacer unispinus Müller, 1776

= Curculio populi: Goeze, 1777: 351; Gmelin, 1790: 1752 (non Linnaeus, 1758, nec Scopoli, 1763)

$=$ Rhinomacer auratus Geoffroy, 1785, syn. nov.

$=$ Curculio populi Paykull, 1792 (non Linnaeus, 1758, nec Scopoli, 1763)

= Curculio violaceus Donovan, 1794 (non Linnaeus, 1758, nec Poda, 1761)

4. RHINOMACER niger, elytris rubris, capite thoraceque aureis, proboscide longitudine fere corporis. Le becmare doré à étuis rouges. Longueur 1 1/4, 2 lignes. Largeur 2/3 1 ligne. Page 270.

4. Rhino / B. doré à etuis rouges. 
Curculio bacchus sensu Fabricius, 1775: $130=$ Curculio purpureus sensu Goeze, 1777: 340 (non Linnaeus, 1758) = Rhinomacer ruber Geoffroy in Fourcroy, 1785: $113=$ Curculio bacchus sensu Gmelin, 1790: 1752 (non Linnaeus, 1758).

There are no specimens in the collection. Schoenherr (1833: 213) placed these nominal species in the synonymy of Rhynchites aequatus (Linnaeus, 1758), and Bedel (1886: 224) did the same. This placement as a synonym of Tatyanaerhynchites aequatus (Linnaeus, 1758) is in agreement with the data in the description and is agreed here.

5. RHINOMACER subvillosus caeruleus. Le becmare bleu à poil. Longueur 1,1 1/2, 2 1/2 lignes. Largeur 1/2, 1, 1 1/4 ligne. Page 271.

5. Rhino / B. bleu a poil.

Curculio violaceus sensu Fabricius, 1775: 141 (non Linnaeus, 1758 ) $=$ Curculio alliariae sensu Goeze, 1777: 337 (non Linnaeus, 1758) = Rhinomacer caeruleus Geoffroy in Fourcroy, 1785: 114 = Curculio violaceus sensu Gmelin, 1790: 1768 (non Linnaeus, 1758).

There should be three specimens on this card, but one is represented by an empty drop of gum, and another by a single glued leg. However, the third is in a good state and can be identified as Neocoenorrhinus pauxillus (Germar, 1824), which, being in accordance with the description, is hereby designated as the lectotype of Geoffroy's nominal species.

Rhinomacer caeruleus meets the requirements of Art. 23.9.1.1 and Rhynchites pauxillus (now Neocoenorrhinus pauxillus) meets those of Art. 23.9.1.2. In accordance with Art. 23.9.2, I hereby consider that the younger name is valid for this species and give evidence that the conditions of Art. 23.9.1.2 are met by quoting the following references: Abbazzi \& Osella, 1992; Antonets \& Barsov, 1998; Barnes, 1959; Barševskis et al., 2004; Blommers \& Vaal, 2002; Calder, 1989; Calder, 1990; Gønget, 2003; Haralamb, 1963; Harman, 2004; Heijerman, 1993; Holecová, 1999; Holecová, 2001; Hoffmann, 1958; Kahn \& Cornell, 1983; Leather, 1996; Lohse, 1981; Mérkl et al., 2003; Morris, 1990; Özbek \& Çalmaşur, 2005; Taylor, 1997; Tertyshny, 1996; Topp et al., 2002; Uusitalo, 2004; Wanat \& Mokrzycki, 2005. This is the 'apple leaf cutter', a serious pest in orchards.

The synonymy is as follows:

Neocoenorrhinus pauxillus (Germar, 1824)

= Curculio violaceus sensu Fabricius, 1775 (non Linnaeus, 1758)

= Curculio alliariae sensu Goeze, 1777 (non Linnaeus, 1758)

= Rhinomacer caeruleus Geoffroy, 1785, syn. nov., nomen oblitum
= Curculio violaceus sensu Gmelin, 1790 (non Linnaeus, 1758)

= Curculio alliariae sensu Rossi, 1790 (non Linnaeus, 1758)

$=$ ? Involvulus sulcidorsum Schrank, 1798

$=$ Rhynchites pauxillus Germar, 1824, nomen protectum

Schoenherr (1833: 231) wrongly synonimized Geoffroy's species with Rhynchites conicus (Illiger, 1807), now a synonym of Involvulus coeruleus (DeGeer, 1775).

6. RHINOMACER nigro-fuscus, glaber, punctatostriatus. Le becmare noir strié. Page 271.

6. Rhino / B. noir strié.

Curculio nigrostriatus Goeze, 1777: $380=$ Rhinomacer niger Geoffroy in Fourcroy, 1785: $114=$ Curculio fuliginosus Gmelin, 1790: 1758.

There are four well-preserved specimens that could be identified, their heads directed towards the central point of the card and the hind body each towards a corner. All of them are Deporaus betulae (Linnaeus). I designate here as lectotype of the three above mentioned nominal species the male specimen at the upper left corner; the other three specimens are paralectotypes. There is another Curculio nigrostriatus Goeze, 1777, described on page 412, which I consider here to be a primary homonym of that on page 380 and here treated, and which is thus an invalid name (Art. 57.2; First Reviser action, see the treatment of the Curculio 26). This other species is a synonym of Cleopomiarus plantarum (Germar, 1824). The synonymy is as follows:

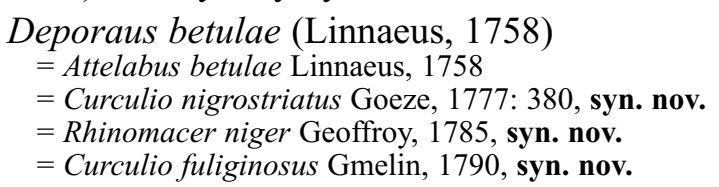

7. RHINOMACER nigro-viridescens, oblongus, striatus. Le becmare allongé. Longueur 1 1/3 ligne. Largeur 1/3 ligne. Page 272.

7. Rhino / B. allongé.

Curculio oblongus Goeze, 1777: 380 (non Linnaeus, 1758) = Rhinomacer oblongus Geoffroy in Fourcroy, 1785: $114=$ Curculio teres Gmelin, 1790: 1758.

There is a single glued specimen, which is an Aspidapion (Koestlinia) aeneum (Fabricius, 1775), in confirmation of the synonymies already registered in the catalogues. Olivier (1807: 32) synonymized Rhinomacer oblongus with Apion aeneum and Schoenherr (1833: 262) synonymized Gmelin's Curculio teres with the same species. Bedel (1887: 366) registered these synonymies and added that of Curculio oblongus. The synonymy is as follows:

Aspidapion (Koestlinia) aeneum (Fabricius, 1775)

$=$ Curculio aeneus Fabricius, 1775

= Curculio oblongus Goeze, 1777 (non Linnaeus, 1758) 
$=$ Rhinomacer oblongus Geoffroy, 1785

$=$ Curculio teres Gmelin, 1790 .

8. RHINOMACER subglobosus, niger, striatus, femoribus rufis. Le becmare noir à pattes fauves. Longueur 1 ligne. Largeur 1/2 ligne. Page 272.

8. Rhino / B. noir a pattes / fauves.

Curculio flavipes sensu Goeze, 1777: 380 (non Fabricius, 1775 , nec Degeer, 1775) = Rhinomacer fulvipes Geoffroy in Fourcroy, 1785: $114=$ Curculio flavipes sensu Gmelin, 1790: 1745 (non Fabricius, 1775, nec Degeer, 1775).

The only specimen is the female lectotype of Protapion fulvipes (Geoffroy, 1785) (= Apion dichroum Bedel, 1886), a synonymy and designation already published (Alonso-Zarazaga, 1988). The pin carries the following labels: (orange) HOLOLECTOTYPUS Rhinomacer fulvipes Fourcr. Alonso-Z. des. 1986 / Apion fulvipes (Fourcr.) = dichroum Bed. Alonso-Z. det. 1986. The synonymy of this species with Apion trifolii (Linnaeus, 1768), given with some doubt by Bedel (1887: 368), is wrong.

9. RHINOMACER subglobosus, villosus, niger, pedibus elytrisque rufis. Le becmare-puce. Longueur 2/3 ligne. Largeur 1/3 ligne. Page 272.

9. Rhino / B. puce.

Curculio pulex Goeze, 1777: $380=$ Rhinomacer minutus Geoffroy in Fourcroy, 1785: $115=$ Curculio pulex Gmelin, 1790: 1758 (non Goeze, 1777).

There are just two specimens, and one drop of gum with almost unidentifiable remains (head and prothorax) on the right. The specimens are one male and one female of Taeniapion rufulum (Wencker, 1864). Bedel (1887: 361) synonymized, probably following Olivier $(1789,1807)$ and with some doubt, Goeze's and Geoffroy's nominal species with Apion malvae (Fabricius, 1775), now Malvapion malvae, to which the remains of the third specimen could belong. The description does not fit any of the species. For the moment, I prefer to keep these nominal species as nomina dubia, although I suspect that the description is probably a mixture of characters of both species.

10. RHINOMACER niger, thorace elytrisque rubris, proboscide longitudine capitis. Le becmare laque. Longueur 1 1/2, 3 lignes. Largeur 2/3, 1 1/4 ligne. Page 273.

10. Rhino / B. laque

Attelabus curculionoides sensu Goeze, 1777: $417=$ Rhinomacer coccineus Geoffroy in Fourcroy, 1785: 115 = Attelabus curculionoides sensu Gmelin, 1790: 1809.

There are four specimens of the common Attelabus nitens (Scopoli, 1763) on the card, glued with their heads directed towards the central point of the card and the hind bodies pointing towards each corner of it. I hereby designate as lectotype of Rhinomacer coccineus Geoffroy the specimen on the front left corner. This synonymy stands from Olivier (1789: 279) and is recorded by Bedel (1886: 222) and Dalla Torre \& Voss (1930: 21). The synonymy is as follows:

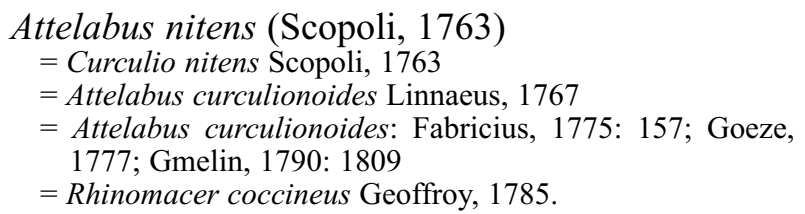

11. RHINOMACER niger, thorace elytrisque rubris, capite pone elongato. La tête écorchée. Longueur 3 lignes. Largeur 1 1/2 ligne. Page 273. Geoffroy quotes Linnaeus (Fauna Svecica, n. 476; 1758: 387, n. 1) and Act. Ups. 1736, p. 19, n.4 (Necydalis rubra...).

11. Rhino / B. tete écorch |. Attelabus coryli sensu Fabricius, 1775: 156 = Attelabus coryli sensu Goeze, 1777: 415 = Rhinomacer coryli sensu Geoffroy in Fourcroy, 1785: 115 = Attelabus coryli sensu Gmelin, 1790: 1808.

No specimens are present in the collection. Schoenherr (1833: 188-9) placed Geoffroy's and Gmelin's records in synonymy of Apoderus coryli (Linnaeus, 1758), since the description does not cast any doubt on it.

12. (*) RHINOMACER striatus. Le Becmare noir à trompe fauve. Long. 1 1/3 lig. Larg. 1/2 lig. R. oblongus, nigro cupreus; pedibus $\&$ proboscide fulvis, punctis elytrorum per strias digestis.

12. Rhino / B. noir a tromp// fauve.

Rhinomacer striatus Geoffroy in Fourcroy, 1785: 115. Geoffroy, 1799: 533.

No specimens are present in the collection. Schoenherr (1833: 238; 1839: 337) placed this species as "incertae sedis". From the description, it could be either Salpingus aeneus (Olivier, 1807) or Salpingus planirostris (Fabricius, 1787).

13. (*) RHINOMACER fulgidus. Le Becmare rouge. Long. 1 1/2 lig. Larg. 1 lig. R. ovatus, striatim punctatus, supra ruber, infra cupreus; antennis, proboscide pedibusque nigris.

13. Rhin / B. rouge.

Rhinomacer fulgidus Geoffroy in Fourcroy, 1785: 116. Geoffroy, 1799: 533.

No specimens are present in the collection. Schoenherr (1833: 238) transferred this species to the genus Rhynchites and Bedel (1886: 224) placed 
it with some doubt under the synonymy of Byctiscus purpureus (Linnaeus) = Tatyanaerhynchites aequatus (Linnaeus, 1758). This placement is not accepted here, and I prefer to keep it as a nomen dubium for the time being.

1. CURCULIO albo nigroque varius, proboscide planiusculâ carinatâ, thoracis longitudine. Le charanson à trompe sillonnée. Longueur 6 lignes. Largeur 3 lignes. Page 278. Geoffroy quotes Linnaeus (Fauna Svec. n. 448, planch. 4, fig. 8) and Frisch (germ. 11, p.32, t. 23, fig. 5).

1. Curculio / C. trompe sillonnée.

Curculio nebulosus sensu Fabricius, 1775: $147=$ Curculio nebulosus sensu Goeze, 1777: 368 (non Linnaeus, 1758) = Curculio nebolusus Geoffroy in Fourcroy, 1785: 116 (an incorrect subsequent spelling) (non Linnaeus, 1758) = Curculio nebulosus sensu Gmelin, 1790: 1787.

The two specimens in the collection are Cleonis pigra (Scopoli, 1763), and are in very good condition; both are in accordance with the original descriptions. This species was synonymized with Curculio sulcirostris Linnaeus, 1767 (a synonym of Cleonis pigra) by Olivier (1807: 259, sub Lixus). I hereby designate as the lectotype of Geoffroy's nominal species the left specimen, and the right one as paralectotype. The synonymy of this species is as follows:

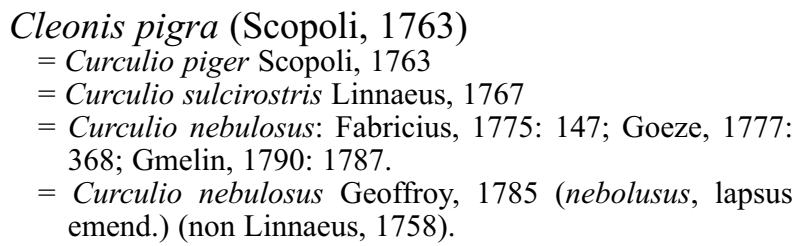

2. CURCULIO totus fuscus rugosus. Le charanson ridé. Longueur 4 lignes. Largeur 2 lignes. Page 278.

2. Curculio / C. ridé.

Curculio rugosus Goeze, 1777: $380=$ Curculio rugosus Geoffroy in Fourcroy, 1785: 117 (non Goeze, 1777, nec Harrer, 1784 ) = Curculio rugosus Gmelin, 1790: 1758 (non Goeze, 1777, nec Harrer, 1784, nec Geoffroy, 1785).

Two specimens are glued side by side on the card. On the left, one Rhytideres plicatus (Olivier, 1790), on the right, one Minyops carinatus (Linnaeus, 1767). The Latin diagnosis and the French description are only in accordance with the latter insect, which I hereby designate as the lectotype of Goeze's, Geoffroy's and Gmelin's nominal species. Herbst (1795: 370) and Schoenherr (1834: 317-8) synonymized Geoffroy's and Gmelin's nominal species with Minyops carinatus and Bedel (1886: 274) did the same with some doubt. The following synonymy is confirmed:
Minyops carinatus (Linnaeus, 1767)

$=$ Curculio carinatus Linnaeus, 1767

= Curculio rugosus Goeze, 1777

= Curculio rugosus Geoffroy, 1785 (non Goeze, 1777, nec Harrer, 1784)

= Curculio scabrosus Villers, 1789 (non Geoffroy, 1785)

$=$ Curculio rugosus Gmelin, 1790 (non Goeze, 1777, nec Harrer, 1784, nec Geoffroy, 1785)

$=$ Curculio senex Rossi, 1790

= Curculio funereus Herbst, 1795 (non Geoffroy, 1785).

3. CURCULIO fusco-nebulosus, thorace sulcato, elytris striatis. Le charanson à corcelet sillonné. Longueur 3 1/2 lignes. Largeur 2 lignes. Page 278.

3. Curculio / C. a corc. sillonné.

Curculio sulcatus Goeze, 1777: 381 (non Fabricius, 1775) = Curculio sulcatus Geoffroy in Fourcroy, 1785: 117 (non Fabricius, 1775, nec Goeze, 1777, nec Schrank, 1781) = Curculio sulcatus Gmelin, 1790: 1758 (non Fabricius, 1775, nec Goeze, 1777, nec Schrank, 1781, nec Geoffroy, 1785).

The only specimen present, in accordance with the description, is a Coniocleonus hollbergi (Fåhraeus, 1842). Bedel (1886: 250) synonymized with some doubt Goeze's and Geoffroy's nominal species with Rhytideres plicatus (Olivier, 1790), a species that does not fit the original description. The synonymy is as follows:

Coniocleonus hollbergii (Fåhraeus, 1842)

= Curculio sulcatus Goeze, 1777 (non Fabricius, 1775), syn. nov.

$=$ Curculio nebulosus Schrank, 1781 (non Linnaeus, 1758)

= Curculio sulcatus Geoffroy, 1785 (non Fabricius, 1775, nec Goeze, 1777, nec Schrank, 1781), syn. nov.

= Curculio glaucus Fabricius, 1787 (non Scopoli, 1763)

$=$ Curculio sulcatus Gmelin, 1790 (non Fabricius, 1775, nec Goeze, 1777, nec Schrank, 1781, nec Geoffroy, 1785), syn. nov.

= Coniocleonus glaucus: auctt.

The name Coniocleonus glaucus (Fabricius, 1787) has been in use for this species, but was rejected some time ago because of the primary homonymy of Curculio glaucus Fabricius, 1787 with Curculio glaucus Scopoli, 1763 (now Phyllobius glaucus). It is, however, open to question whether Fåhraeus's species, described from Central Asia, is conspecific with the common European species usually named C. glaucus, described from Kiel.

4. CURCULIO oblongus, elytris villoso-cinereis, sutura nigra. Le charanson à suture noire. Longueur 5 lignes. Largeur 1 1/2 ligne. Page 279. Geoffroy quotes Linnaeus (Faun. Svec. n. 445) and Acta Ups. 1736, p. 16, n. 1.

4. Curculio / C. a suture noire.

Curculio nigrosuturatus Goeze, 1777: $381=$ Curculio paraplecticus Geoffroy in Fourcroy, 1785: 117 (non Linnaeus, 
$1758)=$ Curculio paraplecticus sensu Gmelin, 1790: 1750 (non Linnaeus, 1758, nec Geoffroy, 1758).

Three Lixus specimens are glued on the card. The middle specimen is Lixus spartii Olivier, 1807, in good condition; it has a blackish suture, but does not not fit the original description in lacking the dark oblique bands running at an angle against this suture. The two lateral specimens are Lixus punctiventris Boheman, 1835, which do not show any trace of blackish sutural band, and are thus not in accordance with Geoffroy's original description. Since none of these specimens can be selected as lectotype for the two nominal species implied, any author that may think that the identity of this species is doubtful may designate a neotype for Coniocleonus nigrosuturatus (Goeze, 1777) in its current sense. I consider that it is not necessary now.

5. CURCULIO fuscus, fulvo maculatus; elytris striatis, striis alternatim nigro maculatis. Le charanson à côtes tachetées. Longueur $31 / 2$ lignes. Largeur 1 2/3 ligne. Page 279.

5. Curculio / C. a cotes tachete|.

Curculio pictus Geoffroy in Fourcroy, 1785: 117 (non Pallas, 1781).

There are two specimens, the one on the right lacking a head, both belonging to the species commonly known as Hypera zoilus (Scopoli, 1763), and agreeing with Geoffroy's description. I hereby designate as lectotype of Curculio pictus Geoffroy the specimen on the left. This synonymy had already been established by Schoenherr (1834: 401) mentioning the "Charanson no 5" of Geoffroy and the C. pictus of Villers under Phytonomus punctatus (Fabricius), and for Geoffroy's nominal species by Bedel (1886: 255) with Hypera punctata (Fabricius). It reads now:

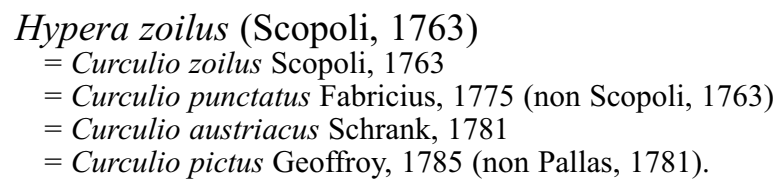

6. CURCULIO oblongus, fuscus, thoracis lateribus albidis, elytris striatis, puncto albo. Le charanson à deux points blancs. Longueur 4 lignes. Largeur 1 $1 / 2$ ligne. Page 280.

6. Curculio / C. a 2 points blancs. Curculio colon sensu Goeze, 1777: 386 = Curculio bipunctatus Geoffroy in Fourcroy, 1785: 118 (non Linnaeus, 1758) = Curculio colon sensu Gmelin, 1790: 1747.

Three well preserved specimens are glued to the card, all fitting the description. They belong to Lepyrus palustris (Scopoli, 1763). I hereby desig- nate the specimen on the right as lectotype of $C$. bipunctatus Geoffroy. This nominal species was synonymized with Curculio colon Linnaeus by Fabricius (1775: 130), a synonymy confirmed by Schoenherr (1834: 330) and Bedel (1886: 272). The synonymy of this species is as follows:

\footnotetext{
Lepyrus palustris (Scopoli, 1763)

$=$ Curculio palustris Scopoli, 1763

= Curculio colon Linnaeus, 1771

= Curculio bipunctatus Harrer, 1784 (non Linnaeus, 1758)

= Curculio bipunctatus Geoffroy, 1785 (non Linnaeus, 1758, nec Harrer, 1784).
}

7. CURCULIO nigro-fuscus, thorace utrinque fascia longitudinali, elytris duplici transversa cinerea. Le charanson à deux bandes transverses. Longueur 9 lignes. Largeur 4 lignes. Page 280.

7. Curculio / C. a bandes transverses.

Curculio transversofasciatus Goeze, 1777: 409 = Curculio fasciatus Geoffroy in Fourcroy, 1785: 118 (non Scopoli, 1763, nec Strøm, 1768, nec Degeer, 1775, nec Müller, 1776) = Curculio fuscatus Gmelin, 1790: 1804.

There is a single insect on the card (on the left) and an empty gum drop (on the right). The only specimen is Leucophyes occidentalis (Dieckmann, 1982), comb. nov. (from Leucosomus), measuring $13.5 \mathrm{~mm}$ long (r.i.). The length and other features of this specimen are not in agreement with the description. The only species inhabiting France and reaching 9 lines long $(20.25 \mathrm{~mm})$ is Larinus onopordi (Fabricius, 1787) which, however, does not reach the Seine basin. It is possible that this specimen has been added after the description was prepared, and that the lost specimen (represented by the empty gum drop) was the one matching the description, but its identity is unknown. Thus, the only specimen cannot be considered a syntype and the above mentioned names are to be considered as nomina dubia.

8. CURCULIO niger, striatus, maculis villoso-fuscis nebulosus. Le charanson tacheté des têtes de chardon. Longueur 2 1/2, 4 lignes. Largeur 1 1/4, 2 lignes. Page 281.

8. Curculio / C. tacheté des tetes / du chardon.

Curculio carduelis Goeze, 1777: $381=$ Curculio cardui Geoffroy in Fourcroy, 1785: 118 (non Herbst, 1784) = Curculio carduelis Gmelin, 1790: 1758 (non Goeze, 1777)

There are two specimens belonging to two different Larinus species, which is reflected by the two measurements given in the description. On the left is a big specimen of Larinus flavescens Germar, 1824 , easily identifiable by the bifid vestiture of the two first abdominal sternites; on the right is a small specimen, apparently a male, of Larinus iaceae 
(Fabricius, 1775). The description is a mixture of characters and partly applicable to each of the two specimens. I designate as the lectotype for the three nominal species the specimen on the right, in order not to disturb greatly the current nomenclature. The synonymy is as follows:

Larinus iaceae (Fabricius, 1775)

$=$ Curculio iaceae Fabricius, 1775

$=$ Curculio carduelis Goeze, 1777, syn. nov.

= Curculio cardui Geoffroy, 1785 [synonymized by Schoenherr, 1836: 122-3]

= Curculio carduelis Gmelin, 1790 (non Goeze, 1777) [synonymized by Schoenherr, 1836: 122-3, under the misspelling C. caurductus (incorrect subsequent spelling)]

= Curculio planus Herbst, 1795 (non Fabricius, 1793).

9. CURCULIO niger, thorace punctato, elytris alternatim striatis \& punctatis. Le charanson brodé. Longueur 3 2/3 lignes. Largeur 1 1/4 lignes. Page 281.

9. Curc. / Ch. brodé.

Curculio striatopunctatus Goeze, 1777: $410=$ Curculio elegans Geoffroy in Fourcroy, 1785: $118=$ Curculio fimbriatus Gmelin, 1790: 1804.

Glued on the card are, from left to right, one cocoon and two adults and, under these, another transversely placed cocoon. The cocoons are empty (although there are larval exuviae of Anthrenus inside). Both specimens are Sphenophorus striatopunctatus (Goeze, 1777) as usually understood, although this genus needs an in-depth revision in the Palaearctic. The specimen on the left is $9.0 \mathrm{~mm}$ long (r. e.), its elytral interstriae (odd and even) are more or less equal in width, the second desmomere is isodiametric; the specimen on the right is $8.5 \mathrm{~mm}$ long (r. e.), the even elytral interstriae are narrower than the odd ones, the second desmomere is clearly oblong. I hereby designate as the lectotype of the three above mentioned nominal species the specimen on the right. Schoenherr (1838: 933) has synonymized Gmelin's species with Sphenophorus mutilatus (Laicharting), while Bedel (1887: 353) synonymized those of Laicharting, Geoffroy and Gmelin with Goeze's species. The synonymy is as follows:

\footnotetext{
Sphenophorus striatopunctatus (Goeze, 1777)

$=$ Curculio striatopunctatus Goeze, 1777

= Curculio mutilatus Laicharting, 1781

= Curculio elegans Geoffroy, 1785

= Curculio fimbriatus Gmelin, 1790 .
}

10. CURCULIO cinereus, squamosus, alis carens, elytris striatis. Le charanson gris, strié \& sans aîles. Longueur 2 1/2, 4 lignes. Largeur 1 1/2, 2 1/4 lignes. Page 282. Geoffroy quotes Linnaeus (Faun. Svec. n. 452) and Lister (loq. p. 394, n. 30).
10. Curculio / C. gris strié et / sans ailes.

Curculio incanus sensu Goeze, 1777: 367 (non Linnaeus, $1758)=$ Curculio incanus sensu Geoffroy in Fourcroy, 1785: 119 (non Linnaeus, 1758) = Curculio incanus sensu Gmelin, 1790: 1785 (non Linnaeus, 1758).

There are four specimens, glued on the card in the form of a cross. The left and rear specimens each lack a head and prothorax. All four specimens are Peritelus sphaeroides Germar, 1824. All the names dealt with here are misidentifications (since Linnaeus is mentioned as author) and, consequently, do not have type material. The synonymy is as follows:

Peritelus sphaeroides Germar, 1824

$=$ Curculio incanus sensu Goeze, 1777 (non Linnaeus, 1758)

$=$ Curculio incanus sensu Geoffroy, 1785 (non Linnaeus, 1758)

= Curculio incanus sensu Gmelin, 1790 (non Linnaeus, 1758).

11. CURCULIO oblongus, totus niger, thorace punctato, elytris sulcatis. Le charanson noir à sillons. Longueur 2 lignes. Largeur 2/3 ligne. Page 282.

11. Curc. / C. noir a sillons.

Curculio sulcatus Goeze, 1777: 410 (non Fabricius, 1775, nec Goeze, 1777: 381) = Curculio incisus Geoffroy in Fourcroy, 1785: 119 = Curculio exaratus Gmelin, 1790: 1804 .

No specimens are present. Goeze named two Geoffroyan species as Curculio sulcatus, the other (on page 381) is here treated under Charanson no. 3 and, acting as First Reviser, I am giving precedence to the latter over the one treated here. Schoenherr (1838: 1064) synonymized with doubt Geoffroy's nominal species with Rhyncolus chloropus sensu Fabricius, 1775 [a misidentification of the species Rhyncolus ater (Linnaeus, 1758)]. The description alone does not permit an assessment to be made as to the accuracy of this supposition, so in my opinion it is better to place these names as nomina dubia.

12. CURCULIO squamoso-viridis, rostro thorace breviore, pedibus rufis. Le charanson à écailles vertes \& pattes fauves. Longueur 2, 3 lignes. Largeur 2/3, 1 1/3 ligne. Page 283. Geoffroy quotes Linnaeus (Faun. Suec. n. 449) and Act. Ups. 1736, p. 16, n. 2.

12. Curc. / C. a ecailles verte// et pattes fauv|/. Curculio pyri sensu Goeze, 1777: 363 (non Linnaeus, 1758) = Curculio argentatus sensu Geoffroy in Fourcroy, 1785: 119 (non Linnaeus, 1758) = Curculio pyri sensu Gmelin, 1790: 1775 (non Linnaeus, 1758).

There are two glued specimens (left and central) and an empty drop on the right. The specimen on the left has black legs and is Polydrusus prasinus (Olivier, 1790); it does not fit the original description because of the leg colour. The central specimen has yellowish legs and is Polydrusus formosus 
(Mayer, 1779). Since all names treated here are misidentifications, there is no need to select a lectotype. However, the only specimen fitting the description is the latter. Mayer's name was reestablished by Alonso-Zarazaga \& Lyal (1999: $175)$ and the synonymy is as follows:

Polydrusus formosus (Mayer, 1779)

= Curculio pyri sensu Goeze, 1777: 363

= Curculio formosus Mayer, 1779 [synonymized with $C$. sericeus by Schoenherr, 1834: 149]

$=$ Curculio sericeus Schaller, 1783 (non Goeze, 1777)

$=$ Curculio argentatus sensu Geoffroy, 1785 (non Linnaeus, 1785)

= Curculio pyri sensu Gmelin, 1790: 1775

= Polydrusus sericeus: auctt.

13. CURCULIO rostro thoracis longitudine, thorace tribus striis pallidioribus. Le charanson à corcelet rayé. Longueur 2 1/2 lignes. Largeur 1 1/2 ligne. Page 283.

13. Curc. / C. a corcelet raye /.

Curculio lineatus sensu Goeze, 1777: 366 (non Linnaeus, 1758) $=$ Curculio fasciolatus Geoffroy in Fourcroy, 1785: 120 = Curculio lineatus sensu Gmelin, 1790: 1784 (non Linnaeus, 1758).

There are three glued specimens. From left to right these are two Hypera postica (Gyllenhal, 1813) and one Sitona lineatus (Linnaeus, 1758). The central specimen is severely damaged, while the one on the left has very well marked lines of pronotal vestiture. The third specimen has an almost non-existent scaly vestiture on head and pronotum, and the elytral scales are etiolated and do not fit the description ("rostro thoracis longitudine"). This species has been wrongly synonymized with Hypera adspersa (Fabricius, 1793) by Schoenherr [1834: 372, with doubt, under Phytonomus pollux (Fabricius, 1801)] and by Csiki (1934: 28, quoting Villers as author). I hereby designate as lectotype of Curculio fasciolatus Geoffroy the left specimen, establishing the synonymy given below.

Curculio fasciolatus meets the requirements of Art. 23.9.1.1 and Rhynchaenus posticus (now Hypera postica) meets those of Art. 23.9.1.2. In accordance with Art. 23.9.2, I hereby consider that the younger name is valid for this species and give evidence that the conditions of Art. 23.9.1.2 are met by quoting the following references: Akiyama \& Oda, 1989; Aldryhim, 1994; Anis-ur-Rahman \& Ellington, 1999; Berberet et al., 1987; Bland, 1984; Grewal \& Dhaliwal, 1983; Gurrea \& Martín, 1985; Harcourt et al., 1981; Hedin et al., 1988; Kimura \& Itoh, 1992; Kusigemati, 1990; Latheef et al.,1979; Mohamed \& Hogg, 2004; Mollet \& Armbrust, 1978; Ohto, 1996; Okumura, 1991; Pajni \& Nanda,
1995; Puttler et al., 1980; Roshandel \& Ebrahimi, 2003; Sabahi \& Kharazi, 2005; Sakurai et al., 2001; Senst \& Berberet, 1980; Skuhrovec, 2006; Wood et al., 1978; Yee \& Harcourt, 1982.

The name Hypera postica applies to a species of economic importance, the 'alfalfa weevil', and is to be kept for the sake of stability. The synonymy is as follows:

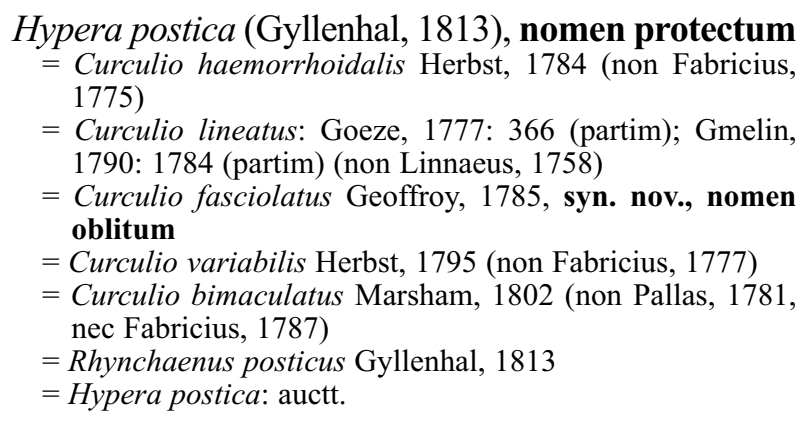

14. CURCULIO rostro thorace breviore, squamis nitentibus, thoracis elytrorumque faciis longitudinalibus. Le charanson écailleux à bandes. Longueur 2 lignes. Largeur 2/3 ligne. Page 284.

14. Curc. / C. écailleux a ban|.

Curculio cupreosquamosus Goeze, 1777: $410=$ Curculio intersectus Geoffroy in Fourcroy, 1785: $120=$ Curculio squamosus Gmelin, 1790: 1804.

There is a single specimen, deprived of its left elytron, agreeing with Geoffroy's description and belonging to Charagmus griseus (Fabricius, 1775). I hereby designate it as lectotype of the three above mentioned nominal species, establishing the following synonymy:

\section{Charagmus griseus (Fabricius, 1775) \\ $=$ Curculio griseus Fabricius, 1775 \\ = Curculio cupreosquamosus Goeze, 1777, syn. nov. \\ $=$ Curculio intersectus Geoffroy, 1785, syn. nov. \\ = Curculio squamosus Gmelin, 1790, syn. nov.}

These three synonyms must be removed from the synonymical list of Sitona lineatus (Linnaeus, 1758), where the first was placed by Bedel (1886: 254), the second by Olivier (1807: 382) and the last by Schoenherr (1834: 109).

15. CURCULIO rufus, subvillosus, capite nigricante, rostro thorace breviore. Le charanson grisette. Longueur 1 1/2 lignes. Largeur 2/3 ligne. Page 284.

15. Curc. / C. grisette.

Curculio griseus Goeze, 1777: 410 (non Fabricius, 1775, nec Müller, 1776) $=$ Curculio modestus Geoffroy in Fourcroy, 1785: 120 (non Fabricius, 1781) = Curculio geoffroaei Gmelin, 1790: 1804 .

A strongly discoloured specimen is glued on the card. It is a specimen of Sitona hispidulus (Fabricius, 
1777), fitting the description. I hereby designate it as lectotype of the three above mentioned nominal species. The synonymy is as follows:

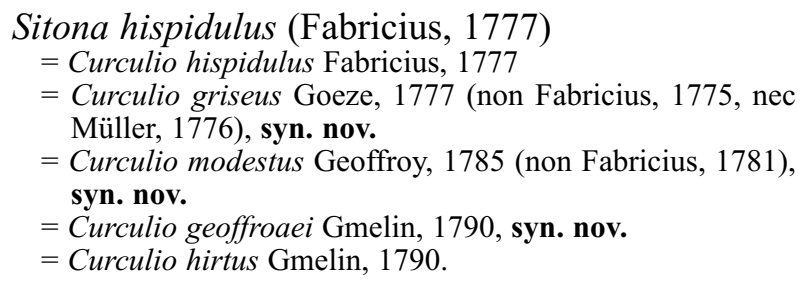

Bedel (1886: 236) presented an erroneous synonymy of these names with Barypeithes pellucidus (Boheman, 1834) (sub Exomias). On the other hand, he should have then renamed the species as Exomias geoffroaei, following the Principle of Priority.

16. CURCULIO caeruleo-viridis nitens, thorace punctato, elytris striatis. Le charanson satin-vert. Longueur 1 1/2 ligne. Largeur 1/2 ligne. Page 284. Geoffroy quotes Petiver (gazoph., p. 77, n. 6).

16. Curc. / C. satin vert.

Curculio viridisericeus Goeze, 1777: $410=$ Curculio viridis Geoffroy in Fourcroy, 1785: $120=$ Curculio gramineus Gmelin, 1790: 1804.

There are two specimens glued to the card, both lacking antennae and legs. On the left is a bright green Baris cuprirostris (Fabricius, 1787), on the right a Baris chlorizans Germar, 1824 which has lost almost all the metallic shine from its body (it seems to have originally been dark blue or violet, but now the brownish colour of the sclerotized tegument is predominant). Geoffroy commented on both specimens, mistaking them for colour varieties. Hustache (1938: 75) quoted C. graminis [sic!] as a synonym of $B$. cuprirostris, while he listed (l.c.: 72) C. viridus [sic!] and C. viridisericeus as synonyms of B. coerulescens (Scopoli, 1763), against Schoenherr's opinion (1836: 706). The latter author included $C$. viridis, $C$. gramineus and Geoffroy's Charanson no. 16 under B. cuprirostris, preferring the latter name, which is 2 years younger, and recorded a variety of the Charanson no. 16 as a synonym of $B$. coerulescens. Bedel (1887: 348) synonymized Goeze's and Geoffroy's nominal species (and also Curculio virens Olivier, 1790) with Baris coerulescens (Scopoli). I hereby designate as lectotype of the three above mentioned names the specimen on the left of the card.

I refrain here from using Goeze's name as valid since Dr. Jens Prena is preparing the declaration of Curculio cuprirostris as a nomen protectum (pers. comm.). The synonymy is as follows:
Aulacobaris cuprirostris (Fabricius, 1787)

$=$ Curculio viridisericeus Goeze, 1777 syn. nov.

$=$ Curculio viridis Geoffroy in Fourcroy, 1785 [synonymized by Schoenherr (1836: 706)]

$=$ Curculio cuprirostris Fabricius, 1787

= Curculio gramineus Gmelin, 1790 [synonymized by Schoenherr (1836: 706) and Hustache (1938: 75)]

= Baris cuprirostris: auctt.

= Aulacobaris cuprirostris: auctt.

17. CURCULIO oblongus, niger; abdomine squamoso, lateribus albis. La pleureuse. Page 285.

17. Curc. / C. pleureuse.

Curculio dolorosus Goeze, 1777: 411 = Curculio funereus Geoffroy in Fourcroy, 1785: 121 = Curculio dolorosus Gmelin, 1790: 1804 (non Goeze, 1777).

No specimens are present. According to the description, it should be a Baridinae with a squamose ventral surface, which is a feature known only from the species of genus Limnobaris Bedel, 1885. Dieckmann (1991: 305), in his revision of the European species of this genus, was of the same opinion. He designated a male neotype, housed in Geoffroy's collection, because the taxonomic situation required it. The synonymy proposed by Dieckmann (1991: 310) is unchanged.

18. CURCULIO rufo-testaceus oblongus, thorace elytrorum fere longitudine. Le charanson brun du bled. Longueur 1 1/2 ligne. Largeur 1/2 ligne. Page 285. Geoffroy quotes Linnaeus (Faun. Svec. n. 462, Syst. nat. ed. 10, p. 378, n. 12) and Ray (Ins. p. 88). 18. Curc. / C. brun du bled.

Curculio granarius sensu Goeze, 1777: 343 = Curculio granarius sensu Geoffroy in Fourcroy, 1785: 121 = Curculio granarius sensu Gmelin, 1790: 1745.

There should be five specimens on the card, but the fourth is missing. All of them are Sitophilus granarius (Linnaeus, 1758). Geoffroy correctly identified the Linnaean species and the following synonymy can be found in Schoenherr (1838: 977):
Sitophilus granarius (Linnaeus, 1758)
= Curculio granarius: Goeze, 1777; Geoffroy in Fourcroy, 1785; Gmelin, 1790.

Check also the Charanson no. 37.

19. CURCULIO rufus, femoribus posticis crassioribus, elytris rufis. Le charanson sauteur brun. Page 286.

19. Curc. / C. sauteur brun.

Curculio ulmi sensu Goeze, 1777: 385 (non Degeer, 1775) = Curculio saltator Geoffroy in Fourcroy, 1785: $121=$ Curculio quercus sensu Gmelin, 1790: 1760 (non Linnaeus, 1758, nec Scopoli, 1763). 
There should be four specimens on the card, but the second is represented by a few remains on a gum drop. All of the remaining three specimens are almost completely devoid of vestiture. The first specimen has yellowish head and rostrum and has been eaten by Anthrenus, which have emptied it (a hole in the apical third of the elytra allows a view of its interior); it is Rhynchaenus quercus sensu Hoffmann. The third, head down, is Rhynchaenus rufus sensu Hoffmann (and it seems that the second was also of this species, from the remains), with black head and yellowish rostrum. The fourth, with black head and rostrum, is Rhynchaenus saltator sensu Hoffmann [= Curculio alni Linnaeus, 1758); cf. Viramo, 1970; the synonymy between Rhynchaenus alni (Linnaeus) and Rhynchaenus saltator (Geoffroy) seems to have been established by Bedel (1887: 290)]. This nominal species is just a phenotype (saltator) of Rhynchaenus alni. Geoffroy made all his comments about this species under the next, since he thought there were only varieties of a single species. According to the description, both species had black head, rostrum and underside of body, being different only in the absence or presence of black spots on the elytra. With these remarks in mind, I hereby designate as lectotype of Curculio saltator Geoffroy the fourth specimen discussed above; I give no status to the other specimens, which do not fit the description. The synonymy is as follows:

Rhynchaenus alni (Linnaeus, 1758)

$=$ Curculio ulmi: Goeze, 1777 (non Degeer, 1775)

$=$ Curculio saltator Geoffroy, 1785

= Curculio quercus: Gmelin, 1790 (non Linnaeus, 1758, nec Scopoli, 1763).

20. CURCULIO rufus, femoribus posticis crassioribus, elytris maculis quatuor nigris. Le charanson sauteur à taches noires. Longueur $11 / 2$ ligne. Largeur 2/3 ligne. Page 286. Geoffroy quotes Linnaeus (Faun. svec. n. 473, Syst. nat. ed. 10, p. 381, n. 34).

20.Curc. /C. sauteur a tach / noires.

Curculio alni sensu Goeze, 1777: $352=$ Curculio alni sensu Geoffroy in Fourcroy, 1785: 122 = Curculio alni sensu Gmelin, 1790: 1760 .

There are five specimens in a row from left to right. The second lacks head and legs, while the fifth has no legs at all. All these specimens belong to Rhynchaenus alni (Linnaeus, 1758) phenotype alni (= ab. quadrimaculatus Gerhardt, 1906): reddish, underside, legs and scutellum black, tarsi and antennae yellowish, elytra with two basal and two larger discal black spots (one on each elytron).
Therefore, Geoffroy had correctly identified the Linnaean species. The synonymy stays as follows:

Rhynchaenus alni (Linnaeus, 1758)

$=$ Curculio alni Linnaeus, 1758

= Curculio alni: Goeze, 1777; Geoffroy, 1785; Gmelin, 1790.

21. CURCULIO cinereus, elytrorum puncto quadruplici nigricante, proboscide thorace breviore. Le charanson quadrille à courte trompe. Longueur 1 1/2 ligne. largeur 2/3 ligne. Page 287.

21. Curc. / C. quadrille a cour / trompe.

Curculio quadrimaculatus sensu Goeze, 1777: 347 (non Linnaeus, 1758) = Curculio quadratus Goeze, 1777: $411=$ Curculio quadrilis Geoffroy in Fourcroy, 1785: 122.

No specimens are present. Very probably a member of Ceutorhynchinae: Phytobiini. These names remain as nomina dubia.

22. CURCULIO cinereus, elytrorum puncto quadruplici albo, proboscide thorace longiore. Le charanson quadrille à longue trompe. Page 287. Geoffroy quotes Linnaeus (1758: 380, n. 25).

22. Curc. / C. quadrille a long|/ trompe.

Curculio quadrimaculatus sensu Fabricius, 1775: 133 (non Linnaeus, 1758) = Curculio quinquemaculatus Geoffroy in Fourcroy, 1785: 122 (non Linnaeus, 1758) = Curculio quadrimaculatus sensu Gmelin, 1790: 1749 (non Linnaeus, 1758).

No specimens are present. The citation of Linnaeus suggests that it could be Nedyus quadrimaculatus (Linnaeus, 1758), but Geoffroy's description does not match this Linnaean species. However, Schoenherr (1837: 512) synonymized it with Ceutorhynchus crucifer (Olivier, 1807), now Ceutorhynchus crucifer (Pallas, 1771) with doubt. This synonymy has been recorded again (as new) in Colonnelli (2004: 61) and I agree with it.

23. CURCULIO niger, ovatus, striatus, totus villoso-cinereus, thorace inermi. Le charanson satin-gris. Longueur 1 1/2 ligne. Largeur 1 ligne. Page 288.

23. Curc. / C. satin-gris.

Curculio griseosericeus Goeze, 1777: 411 = Curculio communis Geoffroy in Fourcroy, 1785: 123 = Curculio cerasi sensu Villers, 1789: 175 (non Linnaeus, 1758) = Curculio asperatus sensu Gmelin, 1790: 1795 (non Bonsdorff, 1785).

This species has already been the subject of a study by Caldara (1990), who did not consider the singleton glued to the card a syntype. This is a male of Tychius breviusculus Desbrochers, 1873, which does not match the description. The above mentioned nominal species were considered incertae sedis and their placement is still doubtful (nomina dubia). 
24. CURCULIO ovatus, nigro-cinereus, thorace utrinque denticulato. Le charanson à corcelet épineux. Page 288.

24. Curc. / C. a corc: epineux.

Curculio thoracespinosus Goeze, 1777: $411=$ Curculio armatus Geoffroy in Fourcroy, 1785: 123 = Curculio denticulatus Gmelin, 1790: 1804 (non Schrank, 1781, nec Geoffroy, 1785).

There are no specimens in the collection. From the description alone, it is clear that this species belongs to the Ceutorhynchinae. However, its identity cannot be fully ascertained. The above mentioned names are thus considered nomina dubia.

25. CURCULIO subrotundus, niger, squamosus, elytris striatis; thorace utrinque aculeato, lateribus lineaque media albis. Le charanson à bandes blanches. Page 288.

25. Curc. / C. a bandes blanches.

Curculio albofasciatus Goeze, 1777: $411=$ Curculio pultiaris Geoffroy in Fourcroy, 1785: 123 = Curculio aculeatus Gmelin, 1790: 1804.

No specimens are present. Colonnelli (1998: 135) proposed, on the sole basis of its description, its synonymy with Nedyus quadrimaculatus (Linnaeus, 1758), with which I agree.

26. CURCULIO subglobosus, cinereo-ater, striatus, proboscide thoracis longitudine. Le charanson noir strié. Longueur 1 ligne. Largeur 1/2 ligne. Page 289.

26. Curc. / C. noir strié.

Curculio nigrostriatus Goeze, 1777: 412 (non Goeze, 1777: 380) $=$ Curculio floriger Geoffroy in Fourcroy, 1785: $123=$ Curculio subglobosus Gmelin, 1790: 1805.

Colonnelli (1998: 135-6) placed Goeze's nominal species incertae sedis, considering that the description did not apply to Ceutorhynchus cochleariae (Gyllenhal, 1813), the nominal species with which the above mentioned species were synonymized by Dalla Torre \& Hustache (1930), based probably on Schoenherr's (1837: 488) synonymy under C. atratulus (Gyllenhal, 1827).

There are three specimens in the collection, each glued to the same card in a reversed ' $\mathrm{V}$ ' configuration. These specimens represent two species: Cleopomiarus plantarum (Germar, 1824) (specimen on the left; previously identified as Gymnetron sp. by Colonnelli, 2004: 14) and Ceutorhynchus obstrictus (Marsham, 1802) (the other two specimens, identified as such by Colonelli, 2004). The specimen on the left matches the description, but the other two do not: they lack all their vestiture and their elytra and legs have a reddish brown to yellowish colour and the rostrum is as long as head plus pronotum or longer. Although Colonelli (2004) designated the specimen on the right (the male) as a lectotype of Curculio nigrostriatus Goeze, 1777, because it fails to match the description I cannot consider it a syntype and accordingly it loses its status as lectotype under Art 74.2. The only true syntype is the specimen on the left, which I hereby designate as lectotype of the three above mentioned nominal species.

Colonnelli (l.c.) declared the nominal species of Goeze, Geoffroy and Gmelin as nomina oblita and Ceutorhynchus obstrictus (Marsham, 1802) as nomen protectum under Art. 23.9, but he failed to "give evidence that the conditions of Article 23.9.1.2 are met", so his designations are invalid. In fact, the name Ceutorhynchus obstrictus was recently adopted for this species by Colonnelli (1993) and has won general acceptance only in the last few years, even if the 'cabbage seedpod weevil' is still (erroneously) named Ceutorhynchus assimilis by many applied entomologists. Given the high number of applied entomology papers on this taxon, it is possible that the name $C$. obstrictus could be declared now a nomen protectum against the only competing name still standing, Curculio napobrassicae Bjerkander, 1780, but this is not the subject of this paper.

The name Curculio nigrostriatus Goeze, 1777: 412 is permanently invalid since it is a primary homonym of the species described by the same author on page 380 (synonymized here with Deporaus betulae (L., 1758) under Rhinomacer no. 6). This is a First Reviser action.

Curculio floriger and Curculio subglobosus meet the requirements of Art. 23.9.1.1 and Cionus plantarum (now Cleopomiarus plantarum) meets those of Art. 23.9.1.2. In accordance with Art. 23.9.2, I hereby consider that the younger name is valid for this species and give evidence that the conditions of Art. 23.9.1.2 are met by quoting the following references: Abbazzi et al., 1995; Alonso-Zarazaga, 2002; Angelov, 1967, 1975, 1980; Arnol'di et al., 1965; Behne, 1989; Caldara, 2005; Compte Sart, 1982; Dieckmann \& Behne, 1994; Heijerman, 1993; Hoffmann, 1958; Jones \& Turkington, 1986; Kocher, 1961; Lohse \& Tischler, 1983; Lucht, 1987; Roudier, 1967; Scherf, 1964; Silvani \& Osella, 2005; Smreczyński, 1973; Strejček, 1993; Tempère, 1978; Tempère \& Péricart, 1989; Viedma, 1961; Wanat \& Mokrzycki, 2005.

The synonymy is as follows:

Cleopomiarus plantarum (Germar, 1824)
$=$ Curculio nigrostriatus Goeze, 1777: 412 (non Goeze,
1777: 380 ), syn. nov. 
$=$ Curculio floriger Geoffroy, 1785, syn. nov., nomen oblitum

= Curculio subglobosus Gmelin, 1790, syn. nov., nomen oblitum

= Cionus plantarum Germar, 1824, nomen protectum

= Miarus plantarum: auctt.

= Cleopomiarus plantarum: auctt.

27. CURCULIO globosus rufus, elytris striatis, fascia transversa alba. Le charanson roux à bande transversale blanche. Longueur 1 ligne. Largeur 2/3 ligne. Page 289.

27. Curc. / C. roux a bande / transv: blanch |. Curculio transversealbofasciatus Goeze, 1777: $412=$ Curculio cinctus Geoffroy in Fourcroy, 1785: 124 (non Drury, 1782, now a Cholus $)=$ Curculio erythroleucos Gmelin, 1790: 1805 .

No specimens are present, although the identity is well known and agreed by most authors. Therefore, I do not think there is need for a neotype designation (Arts. 75.2 and 75.3 of the Code). Colonnelli (1998: 136) proposed the synonymy shown below, with which I fully agree:

Coeliodes transversealbofasciatus (Goeze, 1777)

$=$ Curculio transversealbofasciatus Goeze, 1777

= Curculio cinctus Geoffroy, 1785 (non Drury, 1782)

= Curculio erythroleucos Gmelin, 1790

= Curculio tricinctus Olivier, 1790

= Curculio subrufus Herbst, 1795 (non Gmelin, 1790).

Bedel (1887: 323) synonymized with doubt this species with Ceutorhynchus subrufus (Herbst, 1795), but Olivier (1807: 137) had already established beyond doubt the synonymy of Herbst's and Geoffroy's nominal species.

28. CURCULIO globosus niger, elytris striatis, fascia transversa alba. Le charanson noir à bande transversale blanche. Page 289.

28. Curc. / C. noir a bande / transv. blanche. Goeze (1777:412) gave a phrase ("niger, transverse-albo-striatus"), not a binomen. Curculio vittatus Geoffroy in Fourcroy, 1785: 124 (non Linnaeus, 1758, nec Fabricius, 1781) = Curculio leucozonius Gmelin, 1790: 1805.

No specimens are present. Geoffroy records this species as living on willows. Geoffroy's and Gmelin's nominal species are currently in the synonymy of Nanophyes marmoratus (Goeze, 1777), but the biological data do not fit the habits of this weevil. For the moment, I consider this synonymy as correct.

29. CURCULIO subvilloso-murinus, scutello albicante. Le charanson souris. Longueur 1 ligne. Largeur 1/2 ligne. Page 290.

29. Curc. / C. souris.

Curculio muricatus Goeze, 1777: 412 (non Drury, 1773) = Curculio murinus Geoffroy in Fourcroy, 1785: 124 (non Müller, 1764).
Caldara (1990) also studied this species. There are two specimens glued to the card: the one on the left is a female of Sibiniae viscariae (Linnaeus, 1761) and the one on the right is a male of Tychius crassirostris Kirsch, 1871. Caldara (l. c.) doubted whether both specimens were original and, consequently, syntypes, since they did not match the description. Both names, apart from being primary homonyms, must be placed among the nomina dubia.

30. CURCULIO totus fuscus spinosus, elytris striis elevatis villoso-spinosis. Le charanson à côtes épineuses. Longueur 1 1/2 ligne. Largeur 2/3 ligne. Page 290.

30. Curc. / C. a cotes épineus|.

Curculio spinosus Goeze, 1777: $412=$ Curculio spinifer Geoffroy in Fourcroy, 1785: 125 = Curculio spinosus Gmelin, 1790: 1805 (non Goeze, 1777).

There is a singleton belonging to Trachyphloeus spinosus sensu Hoffmann = Trachyphloeus olivieri sensu Borovec (1989: 413), which I hereby designate as lectotype of the three above mentioned nominal species. I cannot understand why Borovec changed this well known name matching the specimen in Geoffroy's collection. Schoenherr (1837: 505 ) erroneously synonymized $C$. spinosus Gmelin and Charanson no. 30 with Trichosirocalus horridus (Panzer, 1801) (sub Ceutorhynchus). The valid name of the species must return to be the old one under which it has been known almost uniformly:

Trachyphloeus spinosus (Goeze, 1777) stat. res.

= Curculio spinosus Goeze, 1777

= Curculio spinifer Geoffroy, 1785

$=$ Curculio spinosus Gmelin, 1790 (non Goeze, 1777)

= Trachyphloeus olivieri Bedel, 1883.

This synonymy was previously recognized by Bedel (1888: 423), Hoffmann (1950: 246) and Borovec (1989: 413) who, curiously, used Bedel's name.

31. CURCULIO niger, scutello albicante, elytrorum striis utrinque denticulatis. Le charanson noir à côtes. Longueur 1 ligne. Largeur 1/2 ligne. Page 290. 31. Curc. / C. noir a cotes.

Curculio striatodenticulatus Goeze, 1777: $412=$ Curculio denticulatus Geoffroy in Fourcroy, 1785: 125 (non Schrank, 1781) $=$ Curculio armus Gmelin, 1790: 1805 .

No specimens are present. Schoenherr (1837: 541) synonymized it with Ceutorhynchus denticulatus (Schrank, 1781), with doubt. Curiously, Dalla Torre \& Hustache (1930) placed only Geoffroy's name under synonymy of the latter, while leaving those of Goeze and Gmelin as an independent spe- 
cies, Ceutorhynchus striatodenticulatus (Goeze), notwithstanding that they are based on the same description. Colonnelli (2004), aware of the need for fixing the identity of this species, selected a neotype that makes these nominal species a synonym of Ceutorhynchus cochleariae (Gyllenhal, 1813). Moreover, he designated under Art. 23.9 of the Code Goeze's, Geoffroy's and Gmelin's names nomina oblita and Gyllenhal's as nomen protectum, without giving "evidence that the conditions of Article 23.9.1.2 are met" (Art. 23.9.2) by listing the 25 works required by Art. 23.9.1.2, so that his attempt of reversal of precedence is invalid. This deficiency has been communicated to Colonnelli for him to correct.

32. CURCULIO pyriformis nigro-caerulescens abdomine ovato. Le charanson pyriforme. Longueur 1 1/4 ligne. Largeur 1/2 ligne. Page 290.

32. Curc. / C. pyriform.

Curculio acridulus sensu Goeze, 1777: 340 (non Linnaeus, $1758)=$ Curculio acridulus sensu Geoffroy in Fourcroy, 1785: 125 (non Linnaeus, 1758) $=$ Curculio acridulus sensu Gmelin, 1790: 1744 (non Linnaeus, 1758). Geoffroy quotes Linnaeus (Faun. Svec. n. 463, Syst. Nat. ed. 10: 378).

This card should have included five specimens: two front, two central and one rear. The front left is a female Ceratapion (Acanephodus) onopordi (Kirby, 1808), the front right is a male Ceratapion (Ceratapion) gibbirostre (Gyllenhal, 1813), the central left is Anoplus roboris Suffrian, 1840, the central right is represented by an unidentifiable red specimen without a head, and the last is Holotrichapion (Apiops) pisi (Fabricius, 1801). In this mixture, it is the last specimen which seems to me to represent most closely the erroneous Geoffroyan concept of the Linnaean species, as stated in his description; since it is not possible to designate a lectotype for an unavailable name, I only propose to modify the synonymy as follows:

Holotrichapion (Apiops) pisi (Fabricius, 1801)

= Attelabus pisi Fabricius, 1801

= Curculio acridulus: Goeze, 1777; Geoffroy, 1785; Gmelin, 1790 (non Linnaeus, 1758).

The Linnaean species, as usually understood, is Notaris acridulus (Linnaeus, 1758).

33. CURCULIO lividus, coleoptris fasciis plurimis obscuris. Le charanson marbré à bandes. Longueur 2/3 ligne. Largeur 1/3 ligne. Page 291.

33. Curc. / C. marbré a bandes.

Curculio marmoratus Goeze, 1777: 413 = Curculio marmoratus Geoffroy in Fourcroy, 1785: 125 (non Goeze, 1777) = Curculio marnoratus Gmelin, 1790: 1805 (non Goeze, 1777, nec Geoffroy, 1785).
There should have been 8 specimens in two horizontal rows of four each, but the first, fifth, sixth and eighth are missing, leaving only their gum drops. The remaining specimens are all Nanophyes marmoratus (Goeze, 1777) in the usual sense. Bedel (1887: 358) synonymized Geoffroy's Charanson no. 33, Geoffroy's Curculio marmoratus and Fabricius's C. lythri with Goeze's species. I hereby designate as lectotype of the three above mentioned nominal species the seventh specimen (blue dot near it), the other three are paralectotypes. The synonymy is as follows:

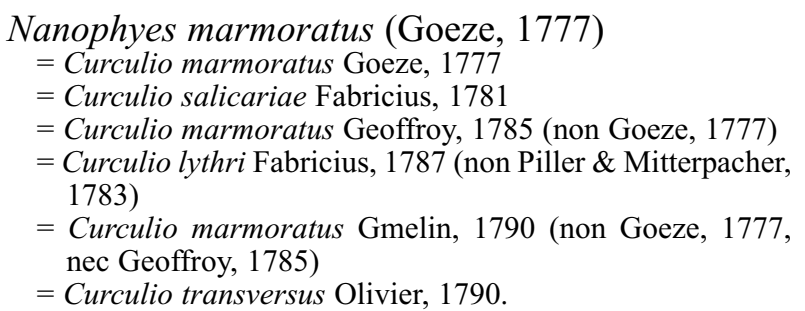

34. CURCULIO niger apterus, thorace utrinque puncto duplici fulvo, basi pilis fulvis coronata. Le charanson à corcelet couronné. Longueur 6 lignes. Largeur 2 1/2 lignes. Page 291.

34. Curculio / C. a corcelet couronné.

Curculio coronatus Goeze, 1777: $395=$ Curculio coronatus Geoffroy in Fourcroy, 1785: 126 (non Goeze, 1777) = Curculio germanus sensu Villers, 1789: 195 (non Linnaeus, 1758) = Curculio coronatus Gmelin, 1790: 1778 (non Goeze, 1777, nec Geoffroy, 1785).

There are three specimens belonging to Liparus coronatus (Goeze, 1777) in the usual sense. I hereby designate as lectotype of the nominal species of Goeze, Geoffroy and Gmelin that on the right, the other two as paralectotypes. The synonymy is established as:

\footnotetext{
Liparus coronatus (Goeze, 1777)

$=$ Curculio coronatus Goeze, 1777

= Curculio coronatus Geoffroy, 1785 (non Goeze, 1777)

= Curculio germanus: Villers, 1789, partim (non Linnaeus, 1758)

$=$ Curculio coronatus Gmelin, 1790 (non Goeze, 1777, nec Geoffroy, 1785).
}

35. (*) CURCULIO scabrosus. Le Charanson noir chagriné. Long. 5 lig. Larg. 2 lig. C. totus niger, nitidus, elytris striatis subrugosis.

35. Curcul. / C. noir chagrin|

Curculio scabrosus Geoffroy in Fourcroy, 1785: 126. Geoffroy, 1799: 534.

There is a single specimen in perfect state, except for the absence of the left hind leg, and which belongs to the concept of Anisorhynchus barbatus sensu Hoffmann. This specimen, which 
fits Geoffroy's description, is here designated as lectotype of Curculio scabrosus Geoffroy.

Although it is clear that Curculio scabrosus meets the requirements of Art. 23.9.1.1, I have been unable to fulfill the requirements of Art. 23.9.1.2 for Anisorhynchus barbatus. Since the latter is not a commonly used name, and has no economical, medical or veterinary importance, I apply here the Principle of Priority (Art. 23). The synonymy is as follows:

Anisorhynchus scabrosus (Geoffroy, 1785), comb. nov.

$=$ Curculio scabrosus Geoffroy, 1785

= Curculio barbatus Rossi, 1794, syn. nov.

However, the true identity of the European species of genus Anisorhynchus Schoenherr, 1842 is subject to much doubt and the reality of the synonymy of a French and an Italian nominal species is in need of clarification.

36 [35]. CURCULIO niger, maculis villoso-flavis, elytris subrugosis. Le Charanson tigré. Longueur 6 lignes Largeur 3 lignes. Page 292.

36. Curculio / C. tigre.

Curculio tigris Goeze, 1777: $395=$ Curculio tigrinus Geoffroy in Fourcroy, 1785: 126 = Curculio abietis sensu Villers, 1789: 195 (non Linnaeus, 1758) = Curculio tigris Gmelin, 1790: 1778 (non Goeze, 1777).

There is a singleton, glued on the left side of the card, to which the description does not apply (unarmed femora, body proportions). This is a female Lixus pulverulentus (Scopoli, 1763) [= Lixus algirus auctt.]. Geoffroy's nominal species is in synonymy with Hylobius abietis (Linnaeus, 1758) in Dalla Torre, Schenkling \& Marshall (1932), while those of Goeze and Gmelin are synonymized with Liparus germanus (Linnaeus, 1758), following Schoenherr (1834: 351). Bedel (1886: 273) synonymized those of Goeze and Geoffroy with Hylobius abietis (followed by Hoffmann, 1955: 635), where I think they should remain, according to the description data. Given that, I do not consider it necessary to designate a neotype. The synonymy is as follows:

Hylobius abietis (Linnaeus, 1758)

= Curculio abietis Linnaeus, 1758

$=$ Curculio tigris Goeze, 1777: 395

= Curculio juniperi Strøm, 1783

= Curculio tigrinus Geoffroy, 1785

= Curculio abietis: Villers, 1789 (non L., 1758)

= Curculio tigris Gmelin, 1790 (non Goeze, 1777), syn. nov.

= Curculio excavatus Schrank, 1798

It is appropriate to address the nomenclature of the species formerly known as Lixus algirus at this point. Thompson \& Alonso-Zarazaga (1988) discovered that both types of Curculio algirus Linnaeus,
1758 fitted the original description and were specimens of the genus Lixomorphus Faust, 1904. Thus the combination Lixomorphus algirus (Linnaeus) was created, leaving Lixus algirus auctt. nec Linnaeus without a name. Among the synonyms of Lixus algirus auctt. is Curculio pulvereus Olivier, 1790, a name proposed by Olivier to replace Curculio pulverulentus Scopoli, 1763. Schoenherr (1836: 43) synonymized Curculio pulverulentus Scopoli, 1763 with Curculio angustatus Fabricius, 1775. It is necessary, for the sake of stability, to restore the oldest available name, as proposed by Bedel (1886: 267) and as advanced under my coordination in Fauna Europaea (Talamelli, 2004), since the change to Lixus angustatus dates back only from 1988. Scopoli's name has priority; the types are lost, but I think there is no need of a neotype for this well known species. The nomenclature is as follows:

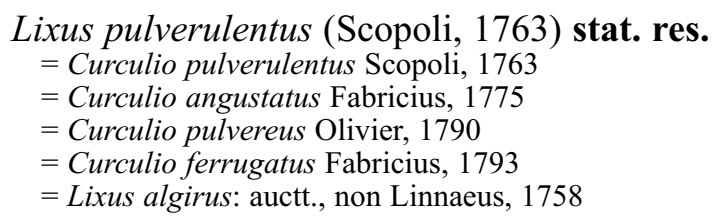

37. (*) CURCULIO contractus. Le Charanson levrier. Long. 2 lig. Larg. 2/3 lig. C. oblongus, totus niger, thorace punctato, elytris striato-punctatis.

37. Curc. / C. levrier.

Curculio contractus Geoffroy in Fourcroy, 1785: 126. Geoffroy, 1799: 534.

There should be ten specimens glued in two horizontal rows of five each, but the third is missing. All of them are Sitophilus granarius (Linnaeus, 1758). This species can be found under two names in Geoffroy's collection (see also the Charanson no. 18). The size given is a bit large and may account for a mistake. The synonymy is as follows:

Sitophilus granarius (Linnaeus, 1758)

$=$ Curculio granarius Linnaeus, 1758

= Curculio contractus Geoffroy, 1785, syn. nov.

38 [36]. CURCULIO cinereus, squamosus, alis carens, elytris rugosis. Le Charanson gris à étuis réunis \& chagrinés. Longueur 6 lignes. Largeur 2 1/2 lignes. Page 292.

38. Curc. / C. gris a etuis / reunis chag|.

Curculio ligustici sensu Goeze, 1777: 362 = Curculio monopterus Geoffroy in Fourcroy, 1785: 127.

Goeze and Villers correctly identified this species, since the two specimens, both females, are Otiorhynchus ligustici in the current sense, and closely match the Geoffroyan description. I hereby 
designate the left specimen as lectotype of Curculio monopterus. The synonymy here confirmed was previously proposed by Schoenherr (1834: 619) and Bedel (1886: 232) and stays as follows:

Otiorhynchus ligustici (Linnaeus, 1758)

= Curculio ligustici Linnaeus, 1758

= Curculio ligustici: Goeze, 1777; Villers, 1789: 202

= Curculio monopterus Geoffroy, 1758 .

39. (*) CURCULIO fuscipes. Le Charanson noir à pattes brunes. Long. 1 lig. Larg. 1/2 lig. C. niger striatus, pedibus fuscis.

39. Curc. / C. noir a pattes / brunes.

Curculio fuscipes Geoffroy in Fourcroy, 1785: 127. Geoffroy, 1799: 534.

No specimens are present. To my knowledge, no author has given an opinion about the identity of this species, which remains a nomen dubium. The description is absolutely insufficient.

40 [37]. CURCULIO fuscus, apterus, elytris rugoso-striatis. Le Charanson cartisanne. Longueur 3, 4 1/2 lig. Largeur 1 1/2, 2 1/2 lig. Page 293.

40. Curc. / C. cartisane.

Curculio rugosostriatus Goeze, 1777: $395=$ Curculio rugosissimus Geoffroy in Fourcroy, 1785: 127 = Curculio corrugatus Gmelin, 1790: 1778.

There is a singleton of which only the elytra and legs remain, although the description suggests two specimens originally present. These remains seem to come from an adelognathous weevil, covered with scales, probably Otiorhynchini or Peritelini, but not Otiorhynchus rugosostriatus sensu Hoffmann, since the elytra of this specimen measure hardly $2.96 \mathrm{~mm}$ by $2.15 \mathrm{~mm}$, too small to match that concept. Bedel (1886: 229) synonymized this species with doubt with Otiorhynchus scabrosus (Marsham, 1802). An interested specialist should designate a neotype for Otiorhynchus rugosostriatus Goeze according to the current concept to keep usage, if there is a need for it.

41 [38]. CURCULIO squamosus, viridi-auratus. Le Charanson à écailles vertes. Longueur 4 lignes. Largeur 1 1/2 lignes. Page 293. Geoffroy quotes Linnaeus (Faun. Svec. n. 459, Sys. Nat. ed. 10: 384, n. 59)

41. Curc. / C. a ecailles vertes.

Curculio argentatus sensu Goeze, 1777: 364 (non Linnaeus, $1758)=$ Curculio auratus Geoffroy in Fourcroy, 1785: 127 (non Scopoli, 1763) = Curculio argentatus sensu Gmelin, 1790: 1776 (non Linnaeus, 1758).

There should be three specimens glued on the card, but the second is missing (only its gum drop remains) and the third is represented only by pieces of the ventral region and a middle leg. The first is a headless female of Phyllobius pomaceus Gyllenhal, 1834, that I designate as a lectotype of Geoffroy's nominal species, since it matches the description. Schoenherr (1834: 438) synonymized in advance Geoffroy's Charanson no. 38 with his interpretation of Phyllobius pyri, and Gmelin's species with Phyllobius argentatus (Linnaeus, 1758), while Bedel (1886: 245) synonymized with doubt the Geoffroyan species with Phyllobius calcaratus (Fabricius, 1793) and Olivier (1807: 416) synonymised it with Phyllobius argentatus (Linnaeus, 1758). The synonymy is completed as follows:

Phyllobius pomaceus Gyllenhal, 1834

= Curculio urticae Degeer, 1775 (non Scopoli, 1763)

= Curculio argentatus: Goeze, 1777; Gmelin, 1790 (non Linnaeus, 1758)

= Curculio auratus Geoffroy, 1785 (non Scopoli, 1763)

$=$ Curculio alneti Fabricius, 1793 (non Schrank, 1781)

= Curculio piri: Herbst, 1795: 295 (non Linnaeus, 1758)

= Phyllobius pyri: Gyllenhal, 1834: 438 (non Linnaeus, 1758)

= Phyllobius urticae: auctt.

The identity of Curculio prasinus Olivier, 1790 is doubtful, since this species is currently found in the literature as both the basionym of Polydrusus prasinus (Olivier, 1790) and as a synonym of Phyllobius pomaceus Gyllenhal, 1834.

42 [39]. CURCULIO oblongus, niger, elytris pedibusque testaceis. Le Charanson à étuis fauves. Longueur 2 1/2 lignes. Largeur 1 ligne. Page 294.

42. Curc. / C. a etuis fauves.

Curculio oblongus sensu Goeze, 1777: $363=$ Curculio querneus Geoffroy in Fourcroy, 1785: 128 = Curculio oblongus sensu Gmelin, 1790: 1775.

There should be six specimens in two rows of three each, however, the second specimen (top row) is wanting. The first (headless), third and fifth are Sitona lineatus (Linnaeus, 1758), the fourth and sixth (both with the head turned to the central point of the card) are Phyllobius (Nemoicus) oblongus (Linnaeus, 1758), these being the only specimens matching the description. Schoenherr (1834: 4489) placed both Geoffroy's and Gmelin's references in synonymy with Phyllobius oblongus (Linnaeus, 1758), and Olivier (1807: 415) added Geoffroy's name to the synonymy of this species. I hereby designate as lectotype of Geoffroy's nominal species the fourth specimen (first of Phyllobius) and as paralectotype the sixth (second of Phyllobius). The synonymy stays as follows:

Phyllobius (Nemoicus) oblongus (Linnaeus, 1758)

$=$ Curculio oblongus Linnaeus, 1758

= Curculio pruni Scopoli, 1763 
= Curculio oblongus: Goeze, 1777; Gmelin, 1790

= Curculio fuscus Laicharting, 1781 (non Goeze, 1777)

$=$ Curculio querneus Geoffroy, 1785

= Curculio mali Fabricius, 1787 (non Fabricius, 1781).

43 [40]. Curculio subglobosus, nigro-fuscus, squamosus, lineolis albis variegatus. Le Charanson géographie. Longueur 2 lignes. Largeur 1 1/2 ligne. Page 294.

43. Curc. / C. geographie.

Curculio geographicus Goeze, 1777: 395 = Curculio geographicus Geoffroy in Fourcroy, 1785: 128 (non Goeze, 1777) = Curculio geographicus Gmelin, 1790: 1778 (non Goeze, 1777, nec Geoffroy, 1785).

The glued singleton belongs to Mogulones geographicus (Goeze, 1777) as usually understood. Schoenherr (1837: 504) synonymized Geoffroy's Charanson no. 40, and Geoffroy's and Gmelin's nominal species, with Ceutorhynchus echii (Fabricius). Bedel (1887: 325) synonymized Curculio echii Fabricius and C. glyphicus Schaller under $C$. geographicus Goeze as the valid name. I hereby designate this specimen as lectotype of the three above mentioned nominal species. The synonymy stays as follows:

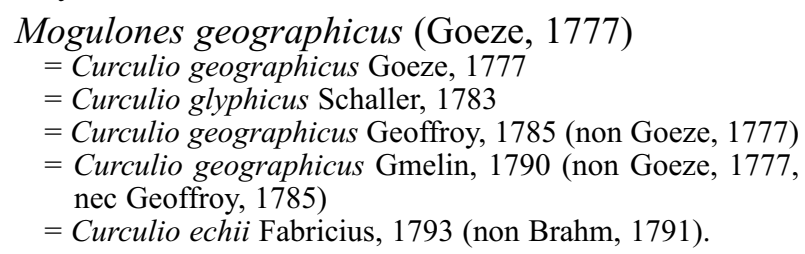

44 [41]. CURCULIO fuscus, elytris striatis macularum albarum fasciâ triplici transversa. Le Charanson brun à bandes transverses de taches blanches. Longueur 4 lignes. Largeur 1 1/2 ligne. Page 295.

44. Curc. / C. brun a bandes / transv. tach. bl |. Curculio transversovittatus Goeze, 1777: $396=$ Curculio stellifer Geoffroy in Fourcroy, 1785: $128=$ Curculio fascialis Gmelin, 1790: 1778.

No specimens are present. Following Bedel (1886: 273), Goeze's name is the valid one for the species formerly known as Hylobius fatuus (Rossi, 1790), an opinion not opposed to since then. The synonymy stays as follows:

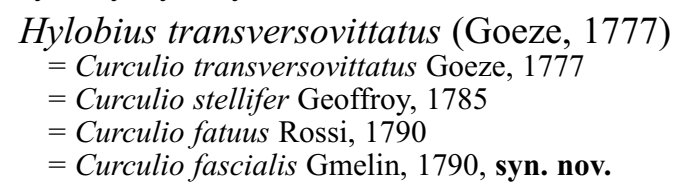

45 [42]. CURCULIO rufo-marmoratus, scutello cordato albo, proboscide subulatâ longissimâ. Le Charanson trompette. Longueur 2, 3, 3 1/2 lignes. Largueur 1, 1 1/2, 2 2/3 lignes. Page 295. Geoffroy quotes Linnaeus (Syst. Nat. ed. 10: 383), Uddmann (dissert.: 24), and Roesel (Ins. tom. 3, suppl. 385). 45. Curc. / C. trompette.

Curculio nucum sensu Goeze, 1777: 358 (non Linnaeus, 1758) = Curculio nucum sensu Geoffroy in Fourcroy, 1785: 129 (non Linnaeus, 1758) = Curculio nucum sensu Gmelin, 1790: 1767 (non Linnaeus, 1758).

Both specimens glued on the card, one female and one male, belong to Curculio venosus (Gravenhorst, 1807) and match Geoffroy's description. Originally at least three specimens were mentioned. Schoenherr (1836: 382) wrongly placed Geoffroy's concept of the Linnaean species under Curculio nucum Linnaeus, 1758. The synonymy is as follows:

Curculio venosus (Gravenhorst, 1807)

= Curculio nucum: Goeze, 1777; Geoffroy, 1785; Gmelin, 1790 (non Linnaeus, 1758)

$=$ Rhynchaenus venosus Gravenhorst, 1807

46 [43]. CURCULIO flavescens, elytris luteo \& rufo tesselatis. Le Charanson damier. Longueur 2 lignes. Largeur 1 ligne. Page 296.

46. Curc. / C. damier.

Curculio druparum sensu Fabricius, 1775: $143=$ Curculio druparum sensu Goeze, 1777: 360 (non Linnaeus, 1761) = Curculio tesselatus Geoffroy in Fourcroy, 1785: 129 (non Fabricius, 1781) $=$ Curculio druparum sensu Gmelin, 1790: 1768 (non Linnaeus, 1761).

No specimens are present. Currently placed in synonymy of both Curculio glandium Marsham, 1802 and Anthonomus (Furcipus) rectirostris (Linnaeus, 1758) in Schenkling \& Marshall (1934). In my opinion some characters fit Curculio villosus Fabricius, 1781 better (size, long, black rostrum and elytra with patchy vestiture), but, for the time being, I prefer to place them as a nomina dubia.

47 [44]. CURCULIO subglobosus niger, punctis duobus atris suturae longitudinalis coleoptrorum, thorace exalbido. Le Charanson à lozange de la scrophulaire. Longueur 3 lignes. Largeur 1 1/2 lignes. Page 296. Geoffroy quotes Linnaeus (Faun. Svec. n. 460, and Syst. Nat. ed. 10: 380, n. 27), Réaumur (Ins. 3, t. 2, f. 12), Act. Ups. (1736, p. 16, n. 5), and Lister (append.: 395).

47. Curc. / C. a lozange scrop|.

Curculio scrophulariae sensu Fabricius, 1775: $140=$ Curculio scrophulariae sensu Goeze, 1777: 359 = Curculio scrophularis Geoffroy in Fourcroy, 1785: 129 = Curculio scrophulariae sensu Gmelin, 1790: 1767.

There are six specimens glued in two rows of three each, belonging to Cionus scrophulariae (Linnaeus, 1758). Only the second and fifth are well preserved. I hereby designate the second specimen as lectotype of Curculio scrophularis Geoffroy, the 
other as paralectotypes. The synonymy stays as follows:

Cionus scrophulariae (Linnaeus, 1758)

= Curculio scrophulariae Linnaeus, 1758

= Curculio scrophulariae: Fabricius, 1775; Goeze, 1777; Gmelin, 1790

$=$ Curculio scrophularis Geoffroy in Fourcroy, 1758 [synonymized by Olivier (1807: 106) and followed by Bedel (1887: 319)].

48 [45]. CURCULIO subglobosus, cinereus, punctis duobus nigris suturae longitudinalis coleoptrorum. Le Charanson gris de la scrophulaire. Longueur 1 1/2 ligne. Largeur 3/4 ligne. Page 298.

48. Curc. / C. gris de la scroph|.

Curculio hortulanus Geoffroy in Fourcroy, 1785: 129.

There are three specimens belonging to genus Cionus, well characterized by the apically awl-shaped rostrum. The first and third specimens are poorly preserved, while the second is a better preserved male, although its vestiture is ruined. I hereby designate the latter as lectotype and the females as paralectotypes. They are Cionus hortulanus (Geoffroy, 1785) in the current sense of most authors.

49 [46]. CURCULIO subglobosus; fusco-nebulosus, maculâ cordatâ albâ in medio dorso. Le Charanson porte-cœur de la scrophulaire. Longueur 1 ligne. Largeur 1/2 ligne. Page 298. Geoffroy quotes Linnaeus (Syst. Nat. edit. 10, p. 380, n. 26) and Act. Ups. 1736, p. 16, n. 7.

49. Curc. / C. porte cour de la / Scrophul. Curculio pericarpius sensu Goeze, 1777: $347=$ Curculio pericarpius sensu Geoffroy in Fourcroy, 1785: 130 (non Linnaeus, 1758).

There is a headless singleton, lacking its vestiture, with reddish elytra. It belongs to subfamily Ceutorhynchinae, tribe Ceutorhynchini. Colonnelli (2004: 37) synonymized this misidentified species with Ceutorhynchus assimilis (Paykull, 1792). However, the latter species does not match the original description.

50 [47]. CURCULIO subglobosus, squamosus, cinereo-fuscus elytrorum maculis tribus \& apice albis. Le Charanson brun à points blancs. Page 299.

50. Curc. / C. brun a points / blancs.

Curculio albopunctatus Goeze, 1777: $396=$ Curculio tripunctatus Geoffroy in Fourcroy, 1785: $130=$ Curculio albopunctatus Gmelin, 1790: 1778 (non Goeze, 1777).

There should be eight specimens in two rows of four each, but the third, sixth, seventh and eighth are missing. All the remaining ones are Nedyus quadrimaculatus (Linnaeus, 1758). Geoffroy's (Charanson no. 47), Fourcroy's and Gmelin's species were synonymized with Coeliodes didymus (Fabricius, 1781) by Schoenherr (1837: 301), while Goeze's was synonymized with Ceutorhynchus quadrimaculatus (Linnaeus) by Bedel (1887: 324). I hereby designate as lectotype of the three above mentioned nominal species the fourth specimen, and the first, second and fifth are paralectotypes. The synonymy is as follows:

Nedyus quadrimaculatus (Linnaeus, 1758)

$=$ Curculio quadrimaculatus Linnaeus, 1758

$=$ Curculio urticae Scopoli, 1763

= Curculio oleraceus Scopoli, 1763

= Curculio albopunctatus Goeze, 1777

= Curculio tripunctatus Geoffroy, 1785

$=$ Curculio albopunctatus Gmelin, 1790 (non Goeze, 1777)

= Curculio viduus Panzer, 1797

= Curculio urticarius [Clairville], 1798 (non Herbst, 1784).

These synonymies have been recorded by Dalla Torre \& Hustache (1930:2, sub Cidnorhinus quadrimaculatus) and recently by Colonnelli (2004).

51 [48]. CURCULIO niger, thorace utrinque dentato. Le Charanson noir à corcelet armé. Longueur 2 lignes. Largeur 1 ligne. Page 299.

51. Curc. / C. noir a corc. arm|.

Curculio aterrimus sensu Fabricius, 1775: 141 (non Linnaeus, $1758)=$ Curculio aterrimus sensu Goeze, 1777: 339 (non Linnaeus, 1758) $=$ Curculio armiger Geoffroy in Fourcroy, 1785: 130 = Curculio cerasi sensu Gmelin, 1790: 1762 (non Linnaeus, 1758).

There is a singleton without elytra, belonging to Magdalis armigera (Geoffroy, 1785), fitting the description perfectly. I hereby designate this specimen as lectotype of Geoffroy's nominal species, as currently understood. Schoenherr (1835: 268) already placed Geoffroy's and Fabricius's species under synonymy of Thamnophilus stygius (Marsham, 1802), while he wrongly placed Gmelin's under Thamnophilus cerasi (Linnaeus, 1758). The synonymy is as follows:

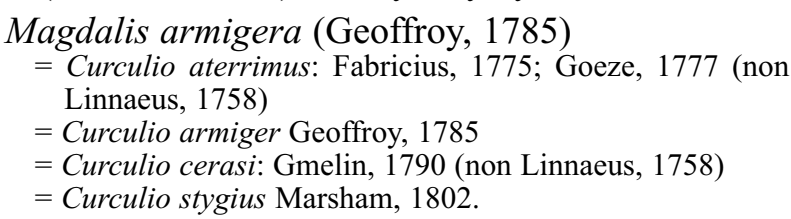

52 [49]. CURCULIO fusco-niger thorace inermi. Le Charanson noir à corcelet sans points. Longueur 1 ligne. Largeur 1/2 ligne. Page 299.

52. Curc. / C. noir a corc. s. poin 1.

Curculio plebeius Geoffroy in Fourcroy, 1785: 131.

No specimens are present. Herbst (1795: 445) considered it to be a synonym of Curculio pruni 
Linnaeus, 1767, itself a synonym of Magdalis ruficornis (Linnaeus, 1758).

53 [50]. CURCULIO fuscus, scutello puncto albo, elytris maculâ rufescente. Le Charanson brun à écusson blanc. Longueur 1 1/2 ligne. Largeur 2/3 ligne. Page 300.

53. Curc. / C. brun a écuss. blan |.

Curculio fuscus Goeze, 1777: $391=$ Curculio scutellatus Geoffroy in Fourcroy, 1785: 131 = Curculio fuscus Gmelin, 1790: 1772 (non Goeze, 1777, nec Laicharting, 1781, nec Olivier, 1790).

No specimens are present. Bedel (1887: 297) synonymized it with doubt under Anthonomus pedicularius (Linnaeus, 1758).

54 [51]. CURCULIO ferrugineus, elytris striatis, oculis nigris. Le Charanson couleur de rouille. Longueur 1 1/4 ligne. Largeur 2/3 ligne. Page 300.

54. Curc. / C. couleur de rouill |.

Curculio tortrix sensu Goeze, 1777: 361 = Curculio rubigineus Geoffroy in Fourcroy, 1785: 131 = Curculio tortrix sensu Gmelin, 1790: 1769.

No specimens are present. Fabricius (1775: 143) synonymized it with Curculio tortrix Linnaeus, 1761, now Dorytomus tortrix, an opinion followed by the majority of later authors, including Bedel (1887: 284).

55 [52]. CURCULIO obscure rufus, villis cinereis aspersus, rostro thorace breviore. Le Charanson velouté. Longueur 2 lignes. Largeur 1 ligne. Page 300 .

55. Curc. / C. velouté.

Curculio sericeus Goeze, 1777: 396 = Curculio villosus Geoffroy in Fourcroy, 1785: 131 (non Fabricius, 1781) = Curculio sericeus Gmelin, 1790: 1778 (non Goeze, 1777, nec Schaller, 1783, nec Piller \& Mitterpacher, 1783).

There are three specimens, the second of which is in a very poor state, lacking the elytra and the abdominal dorsum. The first two specimens are Hypera murina (Fabricius, 1793); they do not match the description, because they do not have toothed femora (Geoffroy placed his species in the Famille 2ème, with toothed femora). The third specimen is Sitona hispidulus (Fabricius, 1777), with its elytral setae of two colours (brown and whitish), which does not match the description, since this mentions only greyish setae. None of the specimens are considered to be syntypes. Although Bedel (1886: 244) gave a doubtful synonymy with Polydrusus marginatus Stephens, 1831, in the present circumstances I consider that the above mentioned names are nomina dubia.
The name on which Hypera murina is based is a junior homonym and, therefore, permanently invalid. It must be replaced with the first available synonym, which is not Curculio fuscocinereus Marsham, 1802, although this has been used by several authors (e.g. Roudier, 1962; Tempère \& Péricart, 1989). The first available synonym is Curculio melancholicus Fabricius, 1793, whose two syntypes I have checked. This specific name, in combination with Hypera as Hypera melancholica (Fabricius, 1793), has been used by Machado \& Oromí (2000) as the valid name of the species, so that this name does not meet the requirements of Art. 23.9.1.1 for the reversal of precedence, even if the requirements of Art. 23.9.1.2 could be fulfilled for Curculio fuscocinereus. Since the latter is not a commonly used name and has no economic, medical or veterinarian importance, I apply here the Principle of Priority (Art. 23) and follow the usage in Machado \& Oromí (2000). The synonymy is as follows:

Hypera melancholica (Fabricius, 1793)

$=$ Curculio murinus Fabricius, 1793 (non Mueller, 1764, nec Geoffroy, 1785)

$=$ Curculio melancholicus Fabricius, 1793 [synonymized by Schoenherr, 1834b: 383]

$=$ Curculio fuscocinereus Marsham, 1802

= Hypera murina: auctt.

= Hypera fuscocinerea: auctt.

56 [53]. CURCULIO oblongus, villis cinereis aspersus, rostro thoraci aequali. Le Charanson vierge. Longueur 1 ligne. Largeur 1/2 ligne. Page 300.

56. Curc. / C. vierge.

Curculio virgo Goeze, 1777: $396=$ Curculio virgo Geoffroy in Fourcroy, 1785: 132 (non Goeze, 1777) = Curculio virgo Gmelin, 1790: 1778 (non Goeze, 1777, nec Geoffroy, 1785).

The only remains of the glued singleton are one elytron and a part of the ventral sclerites. All this belong to a Sitona sp. in my opinion, but I could not identify it. Some of the characters given in the original description, however, do not match this hint. These names are here placed amongst the nomina dubia.

57. (*) CURCULIO punctulatus. Le Charanson noir picoté. Long. 4 lig. Larg. 1 lig. C. totus niger, oblongus, thorace punctato, elytris punctato-striatis, femoribus denticulatis.

57. Curc. / C. noir picoté.

Curculio punctulatus Geoffroy in Fourcroy, 1785: 132. Geoffroy, 1799: 534.

No specimens are present, and the species is of unknown identity (nomen dubium). However, the American Lixus punctulatus (Fabricius, 1787), 
based on Curculio punctulatus Fabricius, 1787, a primary homonym, could be conserved by a request to the International Commission of Zoological Nomenclature under the provisions of Art. 23.9.3.

58. (*) CURCULIO cordifer. Le Charanson à cœur. Long. 1 1/2 lig. Larg. 2/3 lig. C. cinereus, scutello albo, fasciâque elytrorum interruptâ albâ, proboscide longissimâ.

58. Curc. / C. a cœur.

Curculio cordifer Geoffroy in Fourcroy, 85: 132. Geoffroy, 1799: 535.

No specimens are present. Bedel (1887: 352) synonymized this nominal species with Curculio villosus Fabricius, 1781. I accept here this synonymy and do not think there is need for a neotype designation.

59. (*) CURCULIO fasciatus. Le Charanson fascié. Long. 2 lig. Larg. 3/4 lig. C. fusco-cinereus villosus elytrorum suturâ maculisque albis.

59. Curc. / C. fascié.

Curculio fasciatus Geoffroy in Fourcroy, 1785: 133 (non Scopoli, 1763, nec Strøm, 1768, nec Degeer, 1775, nec Müller, 1776). Geoffroy, 1799: 535.

The first time I saw this card there were two specimens in good state. Later, Caldara (1990) found only one which he identified as Tychius quinquepunctatus (Linnaeus, 1758). This syonymy was earlier put forward by Bedel (1887: 313) with some doubt. Lectotypification details are to be found in Caldara (1990).

60. (*) CURCULIO. Not mentioned in works.

60. Curc. / C. tau.

This is a specimen of Archarius crux (Fabricius, 1777).

\section{ACKNOWLEDGEMENTS}

I want to thank here very heartily my good colleague and friend Mll. Hélène Perrin (Muséum National d'Histoire Naturelle, Paris), to whom I owe so many kindnesses and help in the study of the weevils in the Muséum in Paris. She also corrected a first French draft of this paper. My good friend Dr. Christopher H. C. Lyal also commented and gave many suggestions improving a first draft, and substantially improved the submitted English version. Thanks also to Mr. Antonio Sánchez-Ruiz for the photographs.

\section{References}

Abbazzi, P., Colonnelli, E., Masutti, L. \& Osella, G., 1995. Coleoptera Polyphaga XVI (Curculionoidea).
In: A. Minelli, S. Ruffo, S. \& S. La Posta (eds.). Checklist delle specie della fauna italiana, 61. Calderini. Bologna. $68 \mathrm{pp}$

AbBazzi, P. \& Osella, G., 1992. Elenco sistematicofaunistico degli Anthribidae, Rhinomaceridae, Attelabidae, Apionidae, Brenttidae, Curculionidae italiani (Insecta, Coleoptera, Curculionoidea). I Parte. Redia, 75(2): 267-414.

Aguilar, J. D’ \& Raimbault, F., 1990. Notes de bibliographie entomologique. 3. Geoffroy, Fourcroy et l'article $51 \mathrm{du}$ Code de Nomenclature. L'Entomologiste, 46(1): 37-40.

AKIYAMA, H. \& ODA, Y., 1989. Ecology of the alfalfa weevil, Hypera postica (Gyllenhal) in North America. Shokubutsu Boeki, 43(4): 218-221.

AldRYhIM, Y. N., 1994. Seasonal abundance and biology of Hypera postica (Gyllenhal) (Coleoptera: Curculionidae) under irrigation from two different water sources. Arab Gulf Journal of Scientific Research, 12(3): 479-488.

Alonso-Zarazaga, M. A., 1988. Apion whiteheadi, new name for Apion coxale Fall, 1898, nec Desbrochers, 1895, and lectotype designation for Rhinomacer fulvipes Fourcroy, 1785 (Coleoptera: Apionidae). Coleopterists Bulletin, 42(2): 165-166.

Alonso-Zarazaga, M. A., 2002. Lista preliminar de los Coleoptera Curculionoidea del área ibero-balerar, con descriptión de Melicius gen. nov. y nuevas citas. Boletín de la Sociedad Entomológica Aragonesa, 31: 9-33.

Angelov, P., 1964. Die Attelabidae Bulgariens. Entomologische Abhandlungen, 29(12): 627-648.

ANGELov, P., 1967. Rüsselkäfer von der bulgarischen Schwarzmeerküste. Faunistiche Abhandlungen, 2(1): $1-13$.

ANGELOV, P., 1972. Vidov s"stav i razprostranenie na hobotnicite v B"lgariâ. Travaux scientifiques, Biologie, Université de Plovdiv "Païssi Hilendarski", 10(3): 125-137.

Angelov, P., 1980. Coleoptera, Curculionidae. IV čast Calandrinae 2. Fauna na B"lgariâ, 10. B"lgarska Akademiâ na Naukite. Sofiâ. 301 pp.

Angelov, P., 1981. Coleoptera, Rhynchophora (Urodonidae, Anthribidae, Brenthidae, Rhinomaceridae, Attelabidae). Fauna na B"lgariâ, 11. B"lgarska Akademiâ na Naukite. Sofiâ. 112 pp.

Anis-UR-RAhman \& Ellington, J. J., 1999. A survey of the insect parasitoids of alfalfa weevil Hypera postica (Gyllenhal) in the Mesilla Valley, New Mexico, USA. Sarhad Journal of Agriculture, 15(6): 603-606.

Antonets, N. V. \& Barsov, V. A., 1998. Lesopatologičeskoe obsledovanie nasaždenij dneprovsko-orel'skogo zapovednika. Zapovidna Sprava v Ukraïni, 4(2): 56-64. 
ARnol'Di, L. V., ZaslavsKiJ, V. A. \& Ter-Minasyan, M. Y., 1965. 82. Sem. Curculionidae - Dolgonosiki. In: G. A. Bei-Bienko (ed.). Opredelitel" nasekomyh evropejskoj časti SSSR, Vol. 2. Izdatel'stvo „Nauka“. Moscow, Leningrad. 668 pp.

BARNES, M. M., 1959. Deciduous fruit insects and their control. Annual Review of Entomology, 4: 343-362.

BARŠEVSKIS, A., VAlaINIS, U., BIČEVSKIS, M., SAVENKOVS, N., CibuţSKis, R., Kalninş̌, M. \& Strode, N., 2004. Faunistic records of the beetles (Hexapoda: Coleoptera) in Latvia. 1. Acta Biologica Universitatis Daugavpiliensis, 4(2): 93-106.

BEDEL, L., 1882-1888. Faune des Coléoptères du Bassin de la Seine. Vol. VI. Rhynchophora. Annales de la Société entomologique de France, Publication Hors Série. Pp. 1-16 (1882), pp. 17-80 (1883), pp. 81-144 (1884), pp. 145-200 (1885), pp. 201-280 (1886), pp. 281-384 (1887), pp. 385-444 (1888).

BeHNE, L., 1989. Beitrag zur Faunistik der Rüsselkäfer Bulgariens (Coleoptera-Curculionidae). Beiträge zur Entomologie, Berlin, 39(2): 319-341.

Berberet, R. C., Willson, L. J. \& Odejar, M., 1987. Probabilities for encapsulation of eggs of Bathyplectes curculionis (Hymenoptera: Ichneumonidae) by larvae of Hypera postica (Coleoptera: Curculionidae) and resulting reduction in effective parasitism. Annals of the Entomological Society of America, 80(4): 483-485.

BLAND, R. G., 1984. Mouthpart sensilla and mandibles of the adult alfalfa weevil Hypera postica and the Egyptian alfalfa weevil H. brunneipennis (Coleoptera: Curculionidae). Annals of the Entomological Society of America, 77(6): 720-724.

Blommers, L. H. M. \& VaAl, F. W. N. M., 2002. Phenology, damage and parasitoids of the apple leaf cutter Coenorhinus pauxillus (Germ.) (Col.: Attelabidae). Anzeiger für Schädlingskunde (1999. Print), 75(2): 33-40.

BOROVEC, R. 1989. Les espèces françaises du genre Trachyphloeus Germar 1824. Pp. 383-416. In: Tempère, G. \& Péricart, J., q. v.

Brakman, P. J., 1966. Lijst van Coleopteren uit Nederland en het omliggend gebied. Monographieën van de Nederlandsche Entomologische Vereeniging, 2: X $+219 \mathrm{pp}$.

Burakowski, B., MroczKowski, M. \& StefańsKa, J. 1992. Chrzaszcze Coleoptera. Ryjkowcowate prócz ryjkowców - Curculionoidea prócz Curculionidae. Katalog Fauny Polski, 23(18): 1-324 + 1 pl.

CAldara, R., 1990. Su alcuni problemi nomenclaturiali e sinonimici in specie della tribù Tychiini (Coleoptera, Curculionidae). Bollettino della Società entomologica italiana, 122(1): 21-26.

CAldara, R., 2005. Revisione dei Cleopomiarus della Regiona Afrotropicale (Coleoptera Curculionidae).
Memorie della Società Entomologica Italiana, 84: 101-167.

CALDER, A. A., 1989. The alimentary canal and nervous system of Curculionoidea (Coleoptera): gross morphology and systematic significance. Journal of Natural History, 23(6): 1205-1265.

CALDER, A. A., 1990. Gross morphology of the soft parts of the male and female reproductive systems of Curculionoidea (Coleoptera). Journal of Natural History, 24(2): 453-505.

Cameron, H. D., 1988. Geoffroy in Fourcroy, 1785. Sphecos, 17: 6-7.

Colonnelli, E., 1993. The Ceutorhynchinae types of I.C. Fabricius and G. von Paykull (Coleoptera: Curculionidae). Koleopterologische Rundschau, 63 : 299-310.

ColonNelli, E., 2004. Catalogue of Ceutorhynchinae of the World, with a key to the genera (Insecta: Coleoptera: Curculionidae). Argania Editio. Barcelona. $124 \mathrm{pp}$.

Compte Sart, A., 1982. Coleópteros del monte de El Pardo y la Casa de Campo (Madrid). 1. Superfamilia Curculionoidea. Eos (Madrid), 57 [1981]: 17-67.

CsIKI, E., 1934. Curculionidae: Subfam. Hyperinae. In: Schenkling, S. (ed.). Coleopterorum Catalogus, 137: $1-66$.

Dalla Torre, K. W. \& Hustache, A., 1930. Curculionidae: Ceuthorrhynchinae. In: Schenkling, S. (ed.). Coleopterorum Catalogus, 113: 1-150.

Dalla Torre, K. W., Schenkling, S. \& Marshall, G. A. K., 1932. Curculionidae: Subfam. Hylobiinae. In: Schenkling, S. (ed.). Coleopterorum Catalogus, 122: $1-112$.

Dalla Torre, K. W. \& Voss, E., 1930. Curculionidae: Archolabinae, Attelabinae, Apoderinae. In: Schenkling, S. (ed.), Coleopterorum Catalogus, 110: [Archolabinae-Attelabinae]: 1-42; [Apoderinae]: 1-42.

DieCKMANN, L., 1982. Die mitteleuropäischen Leucosomus-Arten. Entomologische Nachrichten und Berichte, 26(4): 145-150.

DieCKMANN, L., 1991. Die europäischen Limnobaris-Arten (Coleoptera, Curculionidae). Beiträge zur Entomologie, Berlin, 41(2): 303-311.

Dieckmann, L. \& Behne, L., 1994. Ergänzungen und Berichtigungen zu Band 11. 93. Familie Curculionidae. U.F. Cleoninae - U.F. Rhynchaeninae. In: G. A. Lohse \& W. H. Lucht (eds.). Die Käfer Mitteleuropas. 3. Supplementband mit Katalogteil. Goecke \& Evers. Krefeld: 259-298.

FABricius, J. C., 1775. Systema Entomologiae, sistens Insectorum classes, ordines, genera, species; adjectis synonymis, locis, descriptionibus, observationibus. Korte. Fleisburgi. $30+832$ pp. 
GeOFfroy, E. L., 1762. Histoire abregée des Insectes qui se trouvent aux environs de Paris; dans laquelle ces animaux sont rangés suivant un ordre méthodique. Vol. 1. Durand. Paris. $28+523$ pp., 10 pl.

Geoffroy, E. L., 1785. In: Fourcroy, A. F. (ed.), Entomologia parisiensis, sive catalogus Insectorum, quae in agro parisiensi reperiuntur; secundum methodum Geoffraeanam in sectiones, genera et species distributus: cui addita sunt nomina trivialia et fere trecentae novae species. Vol. 1. Sub privilegio Academiae. Paris. viii +231 pp.

Geoffroy, E. L., 1799. Histoire abregée des Insectes; dans laquelle ces animaux sont rangés suivant un ordre méthodique. Vol. 1. Calixte-Volland \& Remont. Paris. $28+556$ pp., 10 pl.

Giovanleonardo, A. DI \& Osella. G., 2001. Faunistica ed ecologia del popolamento ad Urodontidae, Anthribidae, Nemonychidae, Attelabidae ed Apionidae del Gran Sasso (Coleoptera, Curculionidea [sic!]). In: B. Cicolani (ed.), Monitoraggio Biologico del Gran Sasso, 2. Andromeda Editrice. L'Aquila: 55106.

Gmelin, J. F., 1790. Caroli A. Linné Systema Naturae. Editio decima tertia, aucta, reformata, cura $G$. F. Gmelin. Vol. 1, part 4. Beer. Lipsiae. Pp. 1517-2224.

GoEze, J. A. E., 1777. Entomologische Beyträge zu des Ritter Linné zwölften Ausgabe des Natursystems. Vol. 1. Weidmanns Erben und Reich. Leipzig. xvi + $736 \mathrm{pp}$.

Gønget, H., 2003. The Nemonychidae, Anthribidae and Attelabidae (Coleoptera) of Northern Europe. Fauna Entomologica Scandinavica, 38. Brill. LeidenBoston. 132 pp.

Grewal, G. S. \& Dhaliwal, J. S., 1983. Antibiosis and tolerance in lucerne to lucerne weevil, Hypera postica (Gyllenhal). Indian Journal of Agricultural Sciences, 53(1): 73-77.

Gurrea, P. \& MArtín, J., 1985. Relationships between bioclimatic factors and the biological cycle in Hypera postica (Gyllenhal) (Coleoptera: Curculionidae). Redia, 68: 91-103.

Haralamb, A. M., 1963. Cultura speciilor forestiere. Editura Agro-Silvică. Bucuresti. 778 pp.

HARMAN, H. M., 2004. Feasibility of biological control of grey willow Salix cinerea. DOC Science Internal Series, 183: 1-29.

Harcourt, D. G., Guppy, J. C., MacLeod, D. M. \& Tyrrell, D., 1981. Two Entomophthora species associated with disease epizootics of the alfalfa weevil, Hypera postica (Coleoptera: Curculionidae), in Ontario. Great Lakes Entomologist, 14(1): 55.

Hedin, P. A., Ellsbury, M. M. \& Dysart, R. J., 1988. Volatiles from clover head Hypera meles (Fab.) and alfalfa $H$. postica (Gyllenhal) weevils: search for pheromones. Experientia (Basel), 44(9): 792-794.

HeIJERMAN, T., 1993. Naamlijst van de snuitskevers van Nederland en het omliggende gebied (Curculionoidea: Curculionidae, Apionidae, Attelabidae, Urodontidae, Anthribidae en Nemonychidae). Nederlandse Faunistiche Mededelingen, 5: 19-46.

Herbst, J. F. W., 1795. Natursystem aller bekannten inund auslandischen Insekten, als eine Fortsetzung der von Büffonschen Naturgeschichte. Der Käfer. Vol. 6. Pauli. Berlin. xxiv +520 pp. + pl. LX-XCV.

Hoffmann, A., 1950. Coléoptères Curculionides (Première Partie). Faune de France, 52: 1-486.

Hoffmann, A. 1958. Coléoptères Curculionides (Troisième Partie). Faune de France, 62: 1209-1839.

HolecovÁ, M. 1999. Struktúra a dynamika spolocenstiev nosácikov (Coleoptera, Curculoinoidea) [sic] v korunách topol'ov na území NPR Súr (JZ Slovensko). Folia faunistica Slovaca, 4: 97-109.

HolecovÁ, M., 2001. Fauna nosáčikov (Coleoptera, Curculionoidea) v okolí vodného diela Żilina. Folia faunistica Slovaca, 6: 81-96

Holecová, M. \& SukupovÁ, J., 2000. Weevils (Coleoptera, Curculionoidea: Attelabidae, Apionidae, Curculionidae) of the Nature reserve Lošonecký háj (SW Slovakia). Folia faunistica Slovaca, 5: 123-134.

HolecovÁ, M. \& ZACH, P., 1996. Prehl'ad fauny chrobákov (Coleoptera) zijúcich na duboch na území Slovenska. A Survey of the Beetle Fauna Living on Oaks in Slovakia. Folia Faunistica Slovaca 1: 39-52.

HORČIČKO, I., 2002. Stability of beetle occurrence inside floodplain forest. Acta Universitatis Palackianae Olomucensis Facultas Rerum Naturalium, Biologica, 39-40 [2001-2002]: 65-79.

InTERnATIONAL COMMISSION ON ZOOLOGICAL NomENClATURE, 1954. Opinion 228. Rejection for nomenclatural purposes of Geoffroy, 1792, Histoire abrégée des Insectes qui se trouvent aux environs de Paris. Opinions and Declarations rendered by the International Commission on Zoological Nomenclature, 4(18): 211-220.

INTERNATIONAL COMMISSION ON ZOOLOGICAL NOMENCLATURE, 1994. Opinion 1754. Histoire abregée des insectes qui se trouvent aux environs de Paris (Geoffroy, 1762): some generic names conserved (Crustacea, Insecta). Bulletin of Zoological Nomenclature, 51(1): 58-70.

Jones, D. A. \& Turkington, R., 1986. Lotus Corniculatus L. The Journal of Ecology, 74(4): 1185-1212.

KAHN, D. M. \& CoRnell, H. V., 1983. Early leaf abscission and folivores: Comments and considerations. The American Naturalist, 122(3): 428-432.

KimurA, H. \& ITOH, N., 1992. Encapsulation of the eggs of Bathyplectes curculionis (Thomson) in larvae of 
Hypera postica (Gyllenhal) in Japan. Research Bulletin of the Plant Protection Service of Japan, 28: 41-45.

Koch, K., 1992. Die Käfer Mitteleuropas. Ökologie. Goecke \& Evers. Krefeld. 389 pp.

Kocher, L., 1961. Catalogue commenté des Coléoptères du Maroc, 9, Rhynchophores. Travaux de l'Institut Scientifique Chérifien, Série Zoologie, 24: 1-263.

Kubisz, D., KuśkA, A. \& PAwłowski, J., 1998. Czerwona Lista Chrząszczy (Coleoptera) Górnego Śląska. Raporty Opinie, 3: 8-68.

Kusigemati, K., 1990. Descriptions of two new ichneumonflies (Hymenoptera) parasitic on alfalfa weevil, Hypera postica (Gyllenhal) (Coleoptera, Curculionidae) from Japan. Japanese Journal of Entomology, 58(3): 619-624.

Latheef, M. A., Parr, J. C. \& Pass, B. C., 1979. Factors affecting survival of Kentucky populations of the alfalfa weevil, Hypera postica (Coleoptera: Curculionidae). Environmental Entomology, 8(6): 1032-1036.

Leather, S. R., 1996. Prunus padus L. The Journal of Ecology, 84(1): 125-132.

Leraut, P., 1981. Les Elateridae décrits par E.L. Geoffroy. L'Entomologiste, 37(2): 95-98.

Lohse, G. A., 1981. U. Fam. Rhynchitinae. In: H. Freude, K. W. Harde \& G. A. Lohse (eds.). Die Käfer Mitteleuropas, Vol. 10. Goecke \& Evers. Krefeld: 113-124.

Lohse, G. A. \& Tischler, Th., 1983. U. Fam. Mecininae. In: H. Freude, K. W. Harde \& G. A. Lohse (eds.). Die Käfer Mitteleuropas, Vol. 11. Goecke \& Evers. Krefeld: 259-283.

Lucht, W. H., 1987. Die Käfer Mitteleuropas. Katalog. Goecke \& Evers. Krefeld. 342 pp.

LundBerG, S., 1995. Catalogus Coleopterorum Sueciae. Naturhistoriska Riksmuseet. Stockholm. Unpaginated.

Machado, A. \& Oromí, P., 2000. Elenco de los Coleópteros de las Islas Canarias. Instituto de Estudios Canarios. La Laguna. $306+$ [2] pp.

Marshall, G. A. K., 1946. Taxonomic notes on Curculionidae (Col.). Annals and Magazine of Natural History, (11), 13: 93-98.

Mérkl, O., Podlussány, A. \& SzÁloki, D., 2003. Ötvenkét bogárcsalád adatai a Látrányi Puszta Természetvédelmi Területról (Coleoptera). Natura Somogyiensis, 5: 139-171.

Mohamed, A. M. A. \& HogG, D. B., 2004. The attachment and stylostome of Trombidium newelli (Acari: Trombidiidae), an ectoparasitic mite on adults of alfalfa weevil, Hypera postica (Coleoptera: Curculionidae). Experimental and Applied Acarology, 34(34): 323-333.
Mollet, J. A. \& Armbrust, E. J., 1978. Age specific serological identification of adult stages of alfalfa weevil, Hypera postica. Annals of the Entomological Society of America, 71(2): 207-211.

Morris, M. G., 1990. Orthocerous Weevils. Coleoptera Curculionoidea (Nemonychidae, Anthribidae, Urodontidae, Attelabidae and Apionidae). Handbooks for the Identification of British Insects, 5(16): 1-108.

O'Brien, C. W. \& WiBmer, G. J., 1984. Annotated checklist of the weevils (Curculionidae sensu lato) of North America, Central America, and the West Indies.Supplement 1. The Southwestern Entomologist, 9(3): 286-307.

Oнто, K., 1996. Effects of photoperiod on the adult diapause in the alfalfa weevil, Hypera postica (Gyllenhal) (Coleoptera: Curculionidae). Research Bulletin of the Plant Protection Service of Japan, 32: $1-6$.

OKUMURA, M., 1991. Alfalfa weevil (Hypera postica): a serious pest of Chinese milk vetch. Honeybee Science, 12(4): 145-150.

Olivier, A. G., 1789. Encyclopédie méthodique. Histoire Naturelle. Insectes, Vol. 4(2). Panckoucke. Paris. 331 pp.

Olivier, A. G., 1807. Entomologie, ou Histoire Naturelle des Insectes, avec leurs caractères génériques et spécifiques, leur description, leur synonymie, et leur figure enluminée. Coléoptères, Vol. 5. Desray. Paris. $612 \mathrm{pp}$.

ÖZBEK, H. \& ÇALMAŞUR, O., 2005. A review of insects and mites associated with roses in Turkey. Acta horticulturae, 690: 167-174.

PAJnI, H. R. \& NANDA, N., 1995. Bionomics of Hypera postica (Gyll.) (Coleoptera: Curculionidae) a pest of Trifolium alexandrinum. Hexapoda (Insecta Indica), 7(2): 85-92.

PoDlussánY, A., 2001. Somogy megye ormányosalkatú bogarainak katalógusa (Coleoptera: Curculionoidea). Natura Somogyensis, 1: 237-252.

PoIRAS, A., 1998. Catalogue of the weevils (Coleoptera, Curculionoidea) and their host plants in the Republic of Moldova. Pensoft Publishers. Sofia-Moscow. 156 pp.

Pye, N., 1972. Leicester and its region. Leicester Univer-sity Press. Leicester. $16 \mathrm{pp}$.

Puttler, B., Hostetter, D. L., Long, S. H. \& Borski, A. A., JR., 1980. Seasonal incidence of the fungus Entomophthora phytonomi infecting Hypera postica larvae in central Missouri. Journal of Invertebrate Pathology, 35(1): 99-100.

Roshandel, S. \& EBrahimi, E., 2003. Biology and seasonal parasitism of Bathyplectes anarus (Thomson), parasitoid of Hypera postica Gill. in Chahar Mahal Va Bakhtiari province. Journal of Entomological Society of Iran, 22(2): 1-15. 
Roudier, A., 1962. Observations et remarques sur divers Curculionides paléartiques (Coléoptères). Revue Scientifique du Bourbonnais, 1962: 31-37.

Roudier, A., 1967. Notes sur certaines espèces du genre Miarus Stephens (Col. Curculionidae). Bulletin de la Société entomologique de France, 71(9-10) [1966]: 276-295.

SABAHI, Q. \& KHARAZI, A., 2005. The effect of larval parasitoids on the control of the alfalfa weevil Hypera postica (Gyllenhal) in Karaj. Applied Entomology and Phytopathology, 72(2): 5-7.

Sakurai, H., OKumura, N. \& Seto, H., 2001. Biological control of the alfalfa weevil, Hypera postica with Metarhizium anisopliae isolated from the soil. Gifu Daigaku Nōgakubu kenkyū hōkoku, 66: 23-30.

Schenkling, S. \& Marshall, G. A. K., 1934. Curculionidae: Anthonominae, Laemosaccinae. In: S. Schenkling (ed.). Coleopterorum Catalogus, 139: 1-82 + $1-8$.

SCHERF, H., 1964. Die Entwicklungsstadien der mitteleuropäischen Curculioniden (Morphologie, Bionomie, Ökologie). Abhandlungen der Senckenbergischen Naturforschenden Gesellschaft, 506: 1-335.

SCHÖNHERR, C. J., 1833-1845. Genera et species curculionidum, cum synonymia hujus familiae. Species novae aut hactenus minus cognitae, descriptionibus a Dom. Leonardo Gyllenhal, C. H. Boheman, et entomologis aliis illustratae. Roret. Paris. Vol. 1(1): I-XV + 1-381; Vol. 1(2): 383-681 [+ 683-685, Corrig.] (1833). Vol. 2(1): 1-326, Vol. 2(2): 329-669 [+ 671-673, Corrig.] (1834). Vol. 3(1) [1836]: 1-505 (1835); Vol. 3(2): 506-858 (1836). Vol. 4(1): 1-600 (1837); Vol. 4(2): 6011121 [+ 1122-1124, Corrig.] (1838). Vol. 5(1): 1456 (1839); Vol. 5(2): 465-970 (1840). Vol. 6(1): 1-474 (1840); Vol. 6(2): 1-495 [489-495, Corrig.] (1842). Vol. 7(1) (1843): 1-479 (1842); Vol. 7(2): 1-461 [454-461, Corrig.] (1843). Vol. 8(1): 1-442 [439-442, Corrig.] (1844); Vol. 8(2): 1-504 [342454 are the Mantissa Curculionidum] (1845).

Senst, K. M. \& Berberet, R. C., 1980. Effects of winter grazing of dormant alfalfa stands on population of Hypera postica (Gyllenhal) (Coleoptera: Curculionidae) and its parasite Bathyplectes curculionis (Thomson) (Hymenoptera: Ichneumonidae). Journal of the Kansas Entomological Society, 53(1): 230234.

Silvani, T. \& Osella, G., 2005. Alcune componenti dell'entomofauna delle aree parasteppiche del Gran Sasso Aquilano. Studi Trentini di Scienze Naturali, Acta Biologica, 81 [2004]: 189-205.

SkUHROVEC, J., 2006. Identification of instars of Hypera postica using chaetotaxy. Journal of Economic Entomology, 99(6): 2216-2218.
SMRECZYŃSKI, S., 1973. Bemerkungen zu einigen Arten der Gattung Miarus Schoenherr, 1826 (non Stephens, 1831) und Beschreibung einer neuen Art (Coleoptera, Curculionidae). Acta zoologica cracoviensia, 18(8): 167-182+ pl. XXII.

Stoltze, M. \& Pihl, S. (eds.), 1998. Rødliste 1997 over planter og dyr i Danmark. Miljø- og Energiministeriet, Danmarks Miljøundersøgelser og Skov- og Naturstyrelsen. København. 219 pp.

StREJČEK, J., 1993. Curculionidae. In: J. Jelínek (ed.). Check-list of Czechoslovak Insects IV (Coleoptera). Seznam československých brouků. Folia Heyrovskiana, Supplementum 1: 135-152.

Talamelli, F., 2004. Fauna Europaea: Curculionidae: Lixinae. Fauna Europaea version 1.4, http://www.faunaeur.org.

TAYLOR, K., 1997. Geum urbanum L. The Journal of Ecology, 85(5): 705-720.

Tempère, G., 1978. Catalogue des Coléoptères Curculionidae de France. Essai de mise à jour critique. Sixième partie. Entomops, 45: 213-232.

Tempère, G. \& Péricart, J., 1989. Coléoptères Curculionidae. Quatrième Partie. Compléments aux trois volumes d'Adolphe Hoffmann. Corrections, Additions et Répertoire. Faune de France, 74: 1-534.

Tertyshny, A. S., 1996. Apple, plum and black currant control from pests using ecologically safety technologies. Acta horticulturae, 422: 328-330.

Thompson, R. T. \& Alonso-Zarazaga, M. A., 1988. On some weevil species described by Linnaeus (Coleoptera, Curculionoidea). Entomologica scandinavica, 19: 81-86.

Topp, W., Kulfan, J., Zach, P. \& Nicolini, F., 2002. Beetle assemblages on willow trees: do phenolic glycosides matter? Diversity and Distributions, 8: 85106.

Uusitalo, M., 2004. European bird cherry (Prunus padus L.) - a biodiverse wild plant for horticulture. Agrifood Research Reports, 61: 1-82.

VIEDMA, M. G. DE., 1961. Curculiónidos de la provincia de Almería. (Coleoptera). Archivos del Instituto de Aclimatación, 10: 43-61.

Villers, CH. DE., 1789. Caroli Linnaei Entomologia, Faunae suecicae descriptionibus aucta, DD. Scopoli, Geoffroy, de Geer, Fabricii, Schrank, etc. speciebus vel in Systemate non enumeratis, vel nuperrime detectis, vel speciebus Galliae Australis locupletata, generum specierumque rariorum iconibus ornata. Vol. 1. Piestre et Delamollière. Lugduni. $24+765$ pp., 3 pl.

VIRAMO, J., 1970. Über die Nomenklatur von Rhynchaenus testaceus (Müll.) (Col. Curculionidae). Annales entomologici Fennici, 36(1): 24-29. 
Voss, E., 1939. Curculionidae: Rhynchitinae II, Allocoryninae, Pterocolinae. In: S. Schenkling (ed.). Coleopterorum Catalogus, 167: 57-130.

WANAT, M. \& MOKRZYCKI, T., 2005. A new checklist of the weevils of Poland (Coleoptera: Curculionoidea). Genus, 16(1): 69-117.

Welch, R. C., 2005. Monks Wood Coleoptera - an update: 1973-2003. English Nature Research Reports, 613: 111-127.

Wood, K. A., Armbrust, E. J., Bartell, D. P. \& Irwin, B. J., 1978. The literature of arthropods associated with alfalfa 5. A bibliography of the alfalfa weevil, Hypera postica (Gyllenhal), and the Egyptian alfalfa weevil, Hypera brunneipennis (Boheman) (Coleoptera: Curculionidae). Special Publications University of Illinois College of Agriculture, 54: 1-92.
Yee, J. M. \& Harcourt, D. G., 1982. Tables of daily development for the life stages of the alfalfa weevil, Hypera postica (Coleoptera: Curculionidae). Proceedings of the Entomological Society of Ontario, 112: 23-27.

Recibido, 23-VIII-2007

Aceptado, 8-IV-2008

Publicado, 30-VI-2008 